\title{
Dioses y antepasados que salen de las piedras
}




\section{Resumen}

Las transformaciones económicas y sociales de comienzos del Holoceno tienen en la progresiva implantación de las figuras humanas en los registros gráficos uno de los más nítidos parámetros de cambio entre las grafías de los cazadores del Paleolítico Superior y las de los agricultores neolíticos. Establecer argumentos acerca del significado de estas imágenes cuenta con la posibilidad contextual que ofrecen las construcciones megalíticas. En este artículo se reflexiona, a partir de la tradición y el conocimiento técnico, sobre el protagonismo de dichas imágenes antropomorfas y su fijación en soporte perdurable, las grandes piedras.

\section{Palabras clave}

Armas blancas I Arqueología I España I Figuras antropomorfas I Megalitismo I Lugares de culto I Necrópolis I Paisaje cultural I Patrimonio arqueológico I Religión

\section{INTRODUCCIÓN}

El interés por el conocimiento del pasado ha venido destacando determinadas facetas de las culturas prehistóricas, entre ellas la religión, entendida las más de las veces como un modo de integrar una naturaleza dura, generadora de miedos y sin control, por parte de conjuntos sociales poco estructurados, que serían los protagonistas de la Prehistoria del sur de Europa, ya fuesen paleolíticos o posteriores.

La idea decimonónica de religión aplicada al arte prehistórico tiene su mejor personificación en Henri Breuil (1974). Su profesión religiosa y su buena formación científica le convierten en el más genuino representante de una línea de análisis que ha tenido continuidad hasta nuestros días. El asentamiento de nomenclaturas como "santuario" aplicadas a las cuevas con arte paleolítico, o la de "ídolos" (BREUIL, 1935), para las diversas figuras humanas grabadas y pintadas del arte postglaciar, protagoniza una perspectiva en la que la religión es el único motor explicativo de los comportamientos humanos antiguos que, de este modo, se redimirían de no haber recibido ni practicado el mensaje cristiano. Así se soluciona por parte de una determinada interpretación de la Historia el "problema" de una humanidad prehistórica con desarrollos simbólicos muy anteriores a lo previsible, según la concepción judeocristiana del origen del hombre.

Si esta interpretación para el arte paleolítico contaba con la oscuridad de las cuevas y el enigmatismo de sus figuras animales, en el caso del arte postglaciar, la notable presencia de figuras humanas encajaba mejor con las imágenes de deificaciones comprensibles en nuestra cultura actual. De ahí que terminologías como "dioses", "ídolos" (L'HELGOUACH, 1983), "religión", o "templos" (LE ROUX, 1985) se hayan aplicado sin ambages al ámbito de los constructores de megalitos en Europa. 
Efectivamente, las transformaciones económicas y sociales de comienzos del Holoceno tienen en la progresiva implantación en los registros gráficos de las figuras humanas uno de los más nítidos parámetros de cambio entre las grafías de los cazadores del Paleolítico Superior y las de los agricultores neolíticos. Con bases subsistenciales en las que los grupos humanos son los gestores de su relación con el entorno, las figuras humanas se erigen en protagonistas de las mitologías colectivas, que se ubican en todos los nichos ecológicos que ocupan (BUENO RAMÍREZ y BALBíN BEHRMANN, 1996b).

Establecer argumentos acerca del significado de estas imágenes cuenta con la posibilidad contextual que ofrecen las construcciones megalíticas. Conocemos su finalidad funeraria y podemos sustentar recorridos cronológicos en los que insertar una evolución conceptual entre las antiguas figuras de los ancestros y las más individualizadas representaciones de guerreros que se extienden por toda Europa a lo largo del III milenio cal a. de C. Quizás uno de los rasgos más interesantes que ofrece la Península Ibérica es la constatación de que los constructores de megalitos se asientan en territorios tradicionales (BUENO RAMÍREZ, en prensa) que han formado parte de sus sistemas de explotación, cuando menos desde el Paleolítico Superior. Y son precisamente los análisis que parten de las evidencias gráficas los que han aportado sólidas referencias para esta hipótesis.

Las rocas al aire libre de los sectores occidentales de los grandes ríos peninsulares, Duero, Tajo y Guadiana, en lo que ahora sabemos, constituyen la mejor biblioteca de un pasado escrito en las piedras. En ellas se almacenan figuras paleolíticas y postpaleolíticas, que demuestran presencias humanas recurrentes en los mismos entornos. Los trabajos de documentación arqueológica (AUBRY, 2001) verifican su asociación con hábitats al aire libre durante el Paleolítico Superior, como sucede en momentos de la Prehistoria Reciente (BUENO RAMÍREZ et al., 2004a). El arte postglaciar no sería, pues, la primera evidencia del uso de marcadores gráficos como delimitadores o identificadores de un territorio, sino que se incluye en una fuerte tradición que sitúa los grabados y pinturas al aire libre como uno de los modos más nítidos de visualizar la posición de los grupos prehistóricos del sur de Europa, desde el Paleolítico Superior en adelante.

La ubicación de destacadas figuras humanas en esos paisajes identificados con las grafías de la tradición insiste en el papel de protagonistas antropomorfos de forma muy señalada a partir del VI milenio cal BC (BUENO RAMÍREZ et al., 2007a; 2008). Los ancestros constituirían uno de los parámetros más destacados para evaluar la ideología de los constructores de megalitos, en el marco de mitologías ampliamente compartidas en el sur de Europa (BUENO RAMÍREZ Y BALBÍN BEHRMANN, 2002), cuyo poso en las religiones antiguas es perceptible a partir de la reiteración de asociaciones y símbolos de notable calado cronológico (BUENO RAMÍREZ et al., 2001). La reflexión que pretendemos establecer

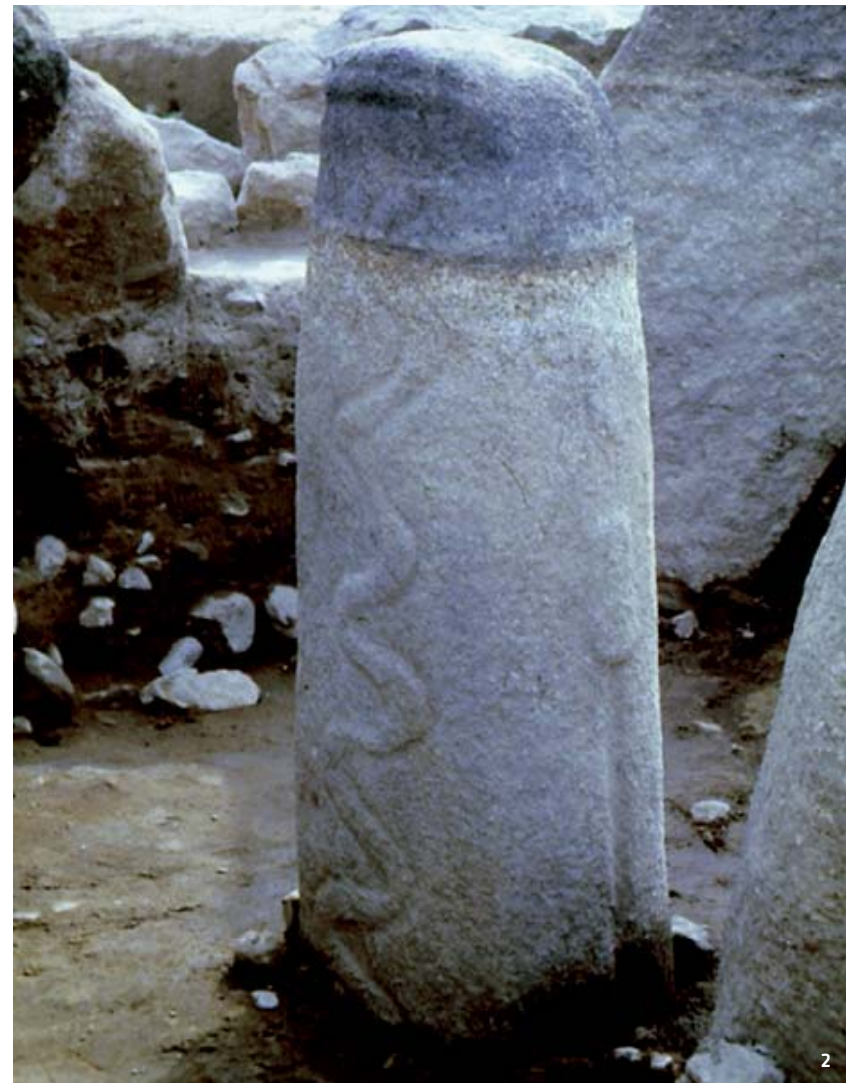

en estas páginas tiene su base en la tradición, el conocimiento técnico, el desarrollo social y la fijación de imágenes antropomorfas como aglutinantes de las áreas de habitación y de enterramiento desde fechas antiguas del arte postglaciar.

\section{IMÁGENES Y NATURALEZA. FORMA Y ESCENARIOS NATURALES}

Siendo el primer escenario de las relaciones sociales, la naturaleza proporcionó a los grupos humanos imágenes que provocaron sentimientos concretos de identificación de lugares, terrenos; en fin, elementos físicos inamovibles, susceptibles de describir y de ver, por su destacado volumen, por su color, o por su notable diferencia respecto a otros elementos del paisaje. La piedra, como materia perdurable, habría sustanciado la estrecha relación entre cultura y naturaleza, mimetizando sugerentes formas naturales con figuras humanas y, viceversa, esculpiendo notables figuras antropomorfas sobre reveladores volúmenes naturales. Este recorrido simbólico no se inicia en la Prehistoria Reciente, sino que se afinca en las sistemáticas técnicas e ideológicas del arte de los cazadores: los 


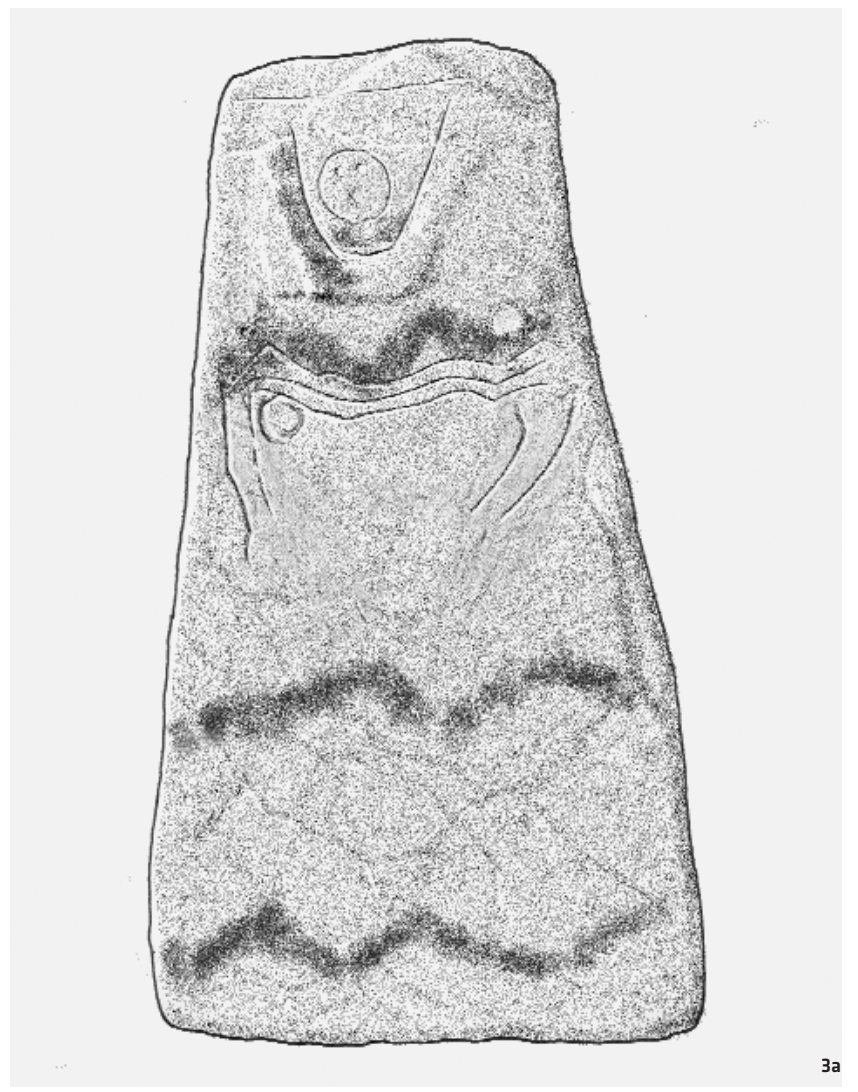

primeros productores son herederos de una larga tradición (BUENO RAMÍREZ et al., 2007b).

No nos cabe duda de que los monumentos megalíticos repiten la imagen de la cueva como el refugio tradicional, el lugar de los ancestros y el de la última morada de los vivos. Pudiéndose haber realizado los megalitos de formas muy diversas, se impone un concepto en el que la montaña (el túmulo) oculta a la cueva (la cámara, con corredor o sin él), donde se depositan los restos humanos. Pudiéndose configurar el corredor como un acceso ancho, cómodo y transitable, se resuelve en la mayor parte de las ocasiones como un recorrido angosto, que obliga a andar en cuclillas, reiterando los estrechos tubos propios del mundo cavernario. Pudiéndose elegir un suelo plano, se tiende a rampas, cuya mayor profundidad a la altura de la cámara (BUENO RAMÍREZ, 1988; 1991) dota a ésta de un aire sensiblemente hipogeo. La cueva aporta, además, el vigor y la fuerza de la piedra, de la materia prima que soporta las embestidas del tiempo y recibe las grafías del pasado.

La mayoritaria orientación este/sureste de los monumentos interactúa con la luz natural, cuyo recorrido destacaría tanto las estelas de los accesos

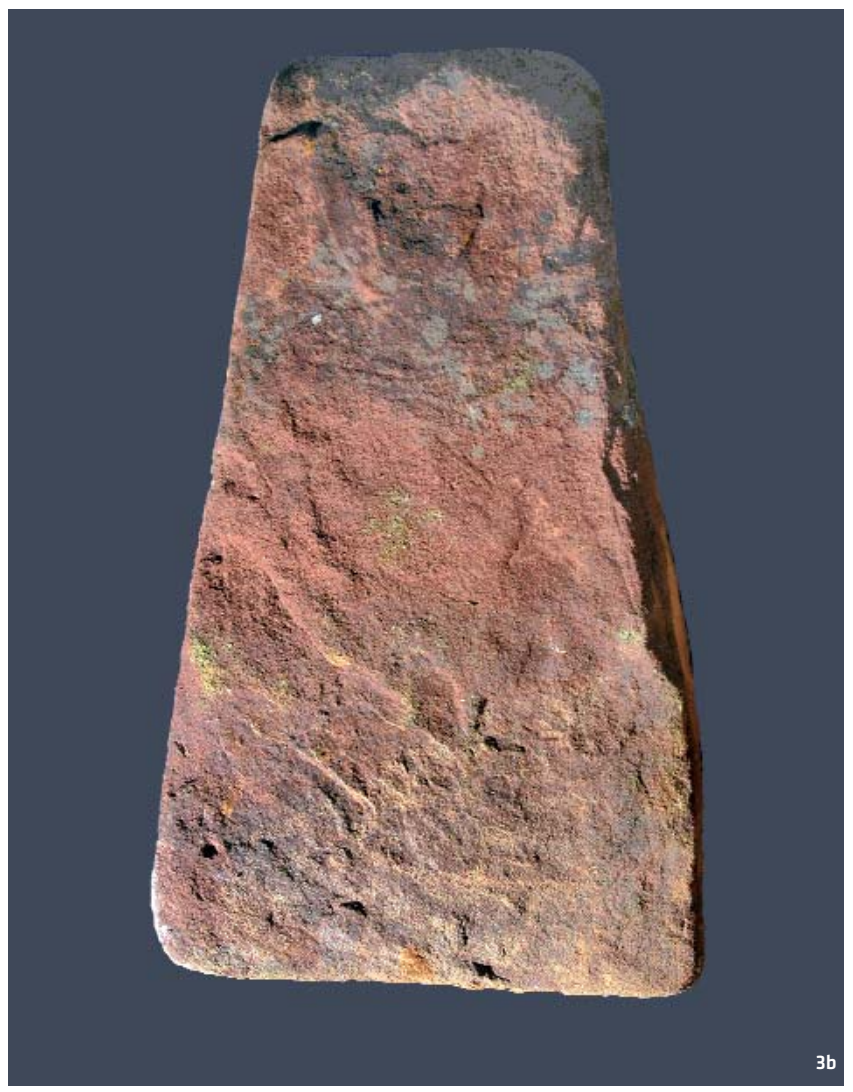

como las piezas escultóricas situadas a la entrada de la cámara, o las decoraciones localizadas en el frontal de ésta. La percepción de un ciclo corto, el representado por la luz que se inicia con el día y se acaba con el ocaso, se sumaría a los ciclos largos asociados a los solsticios, de modo que la conjunción de recursos naturales y construcciones artificiales permitiría percibir las imágenes antropomorfas a la entrada de los monumentos, como los regidores de los tiempos del ciclo vital de sus constructores.

Su posición entre "el cielo y la tierra" (CALADO, 2004), entre la luz y las sombras (L'HELGOUACH, 1996), entre la vida y la muerte los dota de un halo liminar que se acentúa con recursos naturales y artificiales. Pese a la relativa sencillez de los sistemas de talla, los recursos gráficos juegan con la luz solar, buscando perspectivas concretas y destacando determinados atributos. Hemos podido comprobar que si la mayor incidencia solar llega del este, los grabados que identifican más claramente al personaje se ubican en la zona más iluminada por el oriente, normalmente en relieve. Y esto es así en las áreas abiertas o en el acceso a la cámara. El caso del dolmen de Navalcán (Toledo) es muy revelador, las decoraciones en relieve de su estela-menhir se encuentran en las dos caras que recibirían la luz del este, con el levantamiento del día. 
Otras piezas presentan ciertas disimetrías, según las cuales un lateral está más trabajado que el otro. 0 un lateral alinea las grafías en una posición, mientras que el otro las muestra en una situación más alta o más baja que el anterior, quizás para dotar a las estelas y estatuas de cierta perspectiva, jugando, una vez más, con la incidencia de la luz.

Un buen ejemplo es la estela 2 del tholos del complejo funerario de Palacio III (Almadén de la Plata, Sevilla), en la que la cara se ha marcado con un bajorrelieve muy destacado en la zona izquierda, la que recibe la luz desde el este. Los círculos a la altura del pecho también son disimétricos. El izquierdo está a una altura sensiblemente más baja que el derecho, al igual que sucede en otras piezas, como la estela del dolmen de Toconal (Olvera, Cádiz) o, más al norte, en la estela de Soalar (Navarra) (BUENO RAMÍREZ et al., 2005c). Se diría que la profundidad del relieve y la ubicación precisa de cada motivo mantienen una fuerte relación con la incidencia de la luz, señalando un detenido estudio de la posición de las piezas para conseguir el deseado efecto de movimiento y, por qué no decirlo, vida, del mensaje que se pretende transmitir a través de estas imágenes antropomorfas.

Esta noción de tiempo asociada a los recorridos de la luz natural y de movimiento es notoria en la orientación de los paneles al aire libre (BUENO RAMÍREZ et al., 1998), y posee confirmación en los menhires. La tendencia cónica de los menhires dibuja un recorrido circular de su contorno que, con luces indirectas naturales o artificiales, destaca elementos concretos, otorgando tiempo y espacio a la historia escrita en la piedra. La evidencia de que en esos recorridos localizamos en ocasiones temas especulares (BUENO RAMÍREZ et al., 2007a) redunda en esta hipótesis de movimiento. Es el mismo recurso que el de los hermanos Lumière, imágenes repetidas con escasas diferencias, que adquieren movimiento al ser observadas consecutivamente. Si estos mismos monumentos se observasen durante la noche con fuego, aún serían más notables los juegos de luces y sombras, que asociados a la técnica de relieve tan característica de las piezas que nos ocupan conseguirían dibujar personajes de gran impacto visual y una cierta teatralidad.

La concordancia de los recorridos circulares de los menhires, con los mayoritarios en las cámaras, coadyuva a los lazos simbólicos que podemos establecer entre unos y otros. Si los menhires pueden entenderse como imágenes antropomórficas ligadas a la identificación de los grupos humanos (GONÇALVES et al., 1997), cuyos asentamientos presiden, su incorporación a los dólmenes redunda en la interpretación de cada uno de los soportes como una estela de intencionalidad antropomorfa. Las cámaras megalíticas desarrollarían, en su recorrido circular, los mensajes protagonizados por las figuras humanas que se adscribieron inicialmente a los menhires. El sol, con su incidencia en el frontal de la cámara, y el fuego contribuyeron en la consecución de efectos de movimiento con todos los soportes vestidos con manto, elementos básicos de las decoraciones funerarias (BUENO RAMÍREZ Y BALBÍN BEHRMANN, 1992; 1994; 1996b; 1997a; 2003).

La profunda conexión entre los grupos humanos y la naturaleza a lo largo de la historia enlaza en buena medida con su base subsistencial. La vida agropecuaria rige sus tiempos por el sol y la luna, cuyo origen y ocaso han venido asociándose en las mitologías clásicas al de la vida y la muerte de la naturaleza y, por ende, a la humana. De ahí que relacionar la orientación al este de los accesos como metáfora de la entrada de la vida, el sol, y la luz de la luna, hacia el oeste, la oscuridad y la muerte, donde se sitúan la mayor parte de los depósitos humanos, resulte convincente. Los monumentos, con su posición este-oeste, simbolizarían el principio y el fin de la vida, lo que vendría subrayado por el uso del recurso natural de la luz.

En el arte Holoceno, la piedra en soportes naturales adquiere un notable protagonismo, que tiene respuesta en la creación de monumentos artificiales, los dólmenes, auténtica emulación de los espacios naturales, en la medida que conviene a los grupos que los construyeron. Esa medida depende de muchas variables, en las que ahora no vamos a entrar, pero la elegida supone, además del trabajo asumido en la vertiente arquitectónica del monumento, la derivada de la elección de materias primas necesarias para subrayar el discurso simbólico (BUENO RAMÍREZ Y BALBÍN BEHRMANN, 1997b; BUENO RAMÍREZ et al., en prensa a), o para acentuar la visibilidad del monumento (O'SULLIVAN, 1997).

Entre la selección previa, no hay que olvidar la que se refiere a la esencia misma del monumento, aquella que necesita destacar el lazo que une el pasado con el presente, y la que le unirá con el futuro. De ahí que "acoger" piedras de monumentos más antiguos debió ser uno de los preceptos tenidos en cuenta a la hora de la construcción. Más aún cuando estas piedras no son soportes sin más, sino auténticas referencias antropomorfas, cuya integración en los nuevos monumentos visualiza la aceptación del pasado y su exhibición en el sepulcro de los nuevos ancestros (BUENO RAMÍREZ Y BALBÍN BEHRMANN, 1996; BUENO RAMÍREZ et al., 2007a,). Recientemente hemos documentado casos en el megalitismo andaluz, entre los que habría que destacar los de las necrópolis de Antequera por la reiteración de estos gestos, cuyas evidencias se acumulan en Menga, Viera y Romeral, haciendo explícito el valor del pasado en los edificios monumentales de finales del IV y III milenio cal. BC.

Los repetidos gestos de absorción de estelas antiguas en monumentos modernos (BUENO RAMÍREZ et al., 2007a; en prensa b), de integración de cámaras modernas en cámaras antiguas (GARCÍA SANJUÁN Y WHEATLEY, 2006), o de túmulos modernos en túmulos antiguos (BELLO DIÉGUEZ, 1994; FÁBREGAS VALCARCE Y VILASECO VÁZQUEZ, 2006: 31) confirman la intencionalidad expresa de estas recurrencias e insisten en la 
transversalidad cronológica de las expresiones funerarias megalíticas, que proponen una auténtica cadena entre sus más antiguas manifestaciones y las más recientes, verificando idénticas concepciones simbólicas, y sustentando una mitología común a lo largo de más de tres milenios.

Como las rocas señeras del paisaje, los menhires se destacan en los espacios en los que se ubicaron, por su volumen, altura y forma. Y, aunque los indicios no sean muy abundantes (GOMES, 1997a), por su color. Si los dólmenes reflejan la imagen del interior de la tierra, la de la cueva, los menhires reflejan la del exterior, la de los árboles o la de los afloramientos naturales. Su estrecha conexión topográfica a lo largo de todo el desarrollo del megalitismo señala su indisociabilidad, hasta el punto de que nos hemos atrevido a proponer que las necrópolis que no conservan estas indicaciones en piedra pudieron tenerlas en madera (BUENO RAMíREZ et al., 2004a). Serían los menhires en madera o en piedra los auténticos señalizadores de las áreas funerarias y de habitación, de los grupos productores asentados

De este modo, los paisajes megalíticos reproducirían lugares emblemáticos de la naturaleza, cuevas y piedras destacadas, emulando los identificadores más antiguos de los espacios vividos y transitados por el hombre.

\section{LA PIEDRA COMO SOPORTE ESCULTÓRICO DEL CUERPO HUMANO}

Desde el Arte Paleolítico algunas piedras sugirieron figuras humanas, pero el código de estas figuraciones hace de ellas imágenes más animales (DELPORTE, 1979). La interesante constatación de su elaboración simbólica tiene su mejor reflejo en la conceptualización y esquematización que se percibe en las últimas fases del Paleolítico Superior.

Tanto en el arte parietal (BUENO RAMÍREZ et al., 2007b), como, más explícitamente, en el arte mueble (DERRICO, 1994), las imágenes antropomorfas acaban por estar representadas mediante piedras con formas geométricas sencillas y poco trabajo artificial. Nos referimos a los cantos azilienses. Su enorme proximidad morfológica con los que se asocian a las áreas abiertas de los megalitos, y su constatada asociación funeraria (COUREAUD, 1985; DERRICO Y POSSENTI, 1999), insiste en el largo recorrido simbólico y conceptual que une las producciones de los cazadores y de los productores del sur de Europa (BUENO RAMÍREZ Y BALBÍN BEHRMANN, 1994; 1996b; BUENO RAMÍREZ et al., 2007b).

En los megalitos, disponemos de asociaciones explícitas entre formas más y menos elaboradas que proponen una transmutación de papeles entre las naturales o casi naturales, y las artificiales, que aboga por dotar a estos conjuntos de papeles idénticos (BUENO RAMÍREZ et al., 2005b).
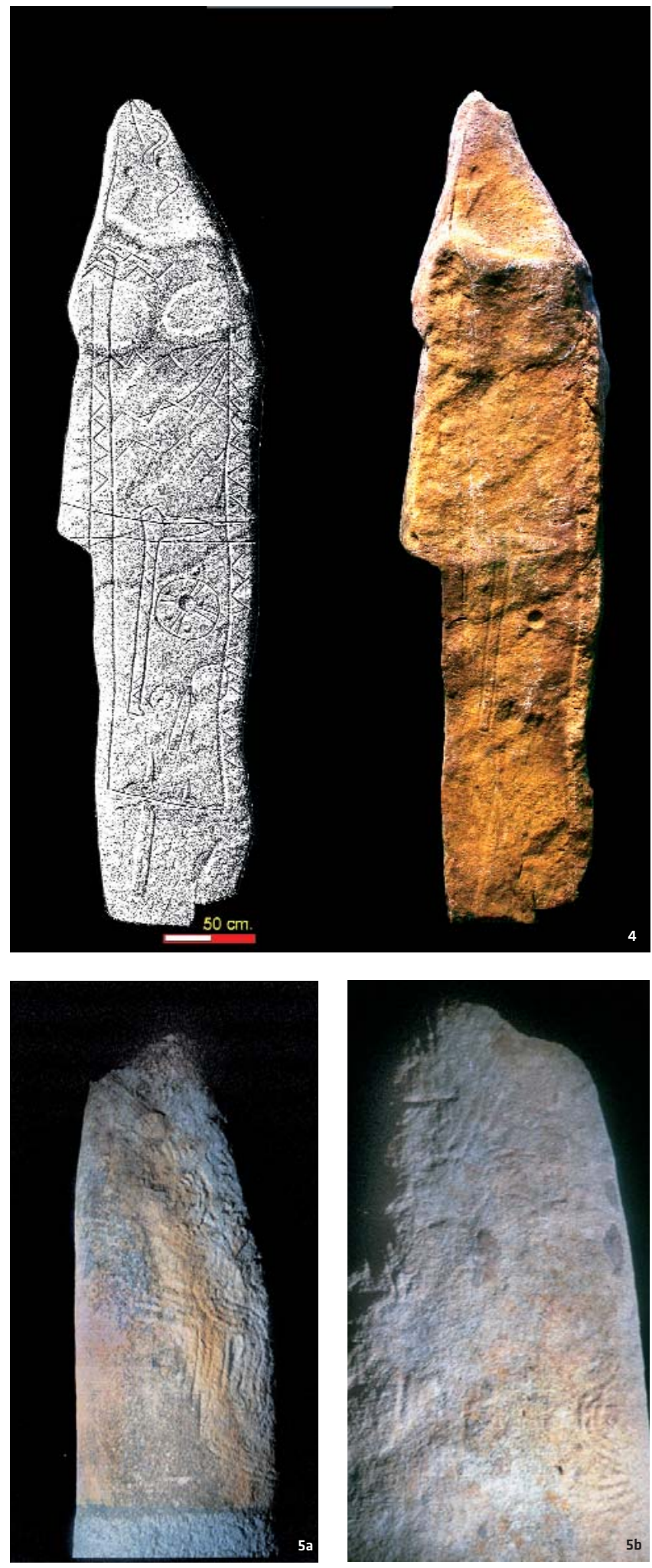


\begin{tabular}{|c|c|c|c|c|c|}
\hline \multirow[t]{2}{*}{ Asturias } & $\begin{array}{l}1 \\
2 \\
\end{array}$ & \begin{tabular}{|l|} 
Baradal \\
Paniciegas \\
\end{tabular} & & & \\
\hline & 3 & Argalo & Cᄃ & Atrio & \multirow{4}{*}{ Monumento 2: 5353 / 2910 a.de C. } \\
\hline \multirow{3}{*}{ Galicia } & 4 & Axeitos & Cᄃ & & \\
\hline & 5 & Dombate & CC & Atrio & \\
\hline & 6 & Parxubeira & CC & Atrio & \\
\hline \multirow{7}{*}{ Cataluña } & 7 & Can Morota 3 & c & & \\
\hline & 8 & Serra del Vent & & & \\
\hline & 9 & C. Nta Sra do Monte & CC & Atrio & \multirow{8}{*}{$4720+/-40$ BP (OXA-4484) } \\
\hline & 10 & Cortiço & CC & Atrio & \\
\hline & 11 & Cova do Moura & CC & Atrio & \\
\hline & 12 & Modorras I & CC & Atrio & \\
\hline & 13 & Lameira da Cima & $\mathrm{CC}$ & Atrio & \\
\hline \multirow{11}{*}{ Portugal } & 14 & Mohínos do Vento & CC & Atrio & \\
\hline & 15 & Orca dos Padrôes & CC & Cámara & \\
\hline & 16 & Pena Mosqueira & & & \\
\hline & 17 & Portela do Pau & c & Atrio & $5087+/-31$ BP (CSIC-1119) \\
\hline & & & & & $5131+/-28$ BP (CSIC-1120) \\
\hline & & & & & $5435+/-44$ BP (CSIC-1121) \\
\hline & 18 & Sao Pedro dias & CC & Atrio & \\
\hline & 19 & Turgal & Cᄃ & Atrio & \\
\hline & 20 & Touta & CC & Túmulo & \\
\hline & 21 & Azután & CC & Atrio & \multirow{4}{*}{$5270+/-140$ (GrN-16073) } \\
\hline & 22 & Fuentepecina & $\mathrm{CC}$ & & \\
\hline \multirow[t]{2}{*}{ Meseta } & 23 & Los Zumacales & CC & & \\
\hline & 24 & Veguilla III & CC & & \\
\hline \multirow{2}{*}{ Extremadura } & 25 & Tricones i & CC & Atrio & \\
\hline & 26 & Lagunita III & $\mathrm{CC}$ & Túmulo & \\
\hline Andalucía & 27 & Alberite & G & Atrio & \\
\hline
\end{tabular}

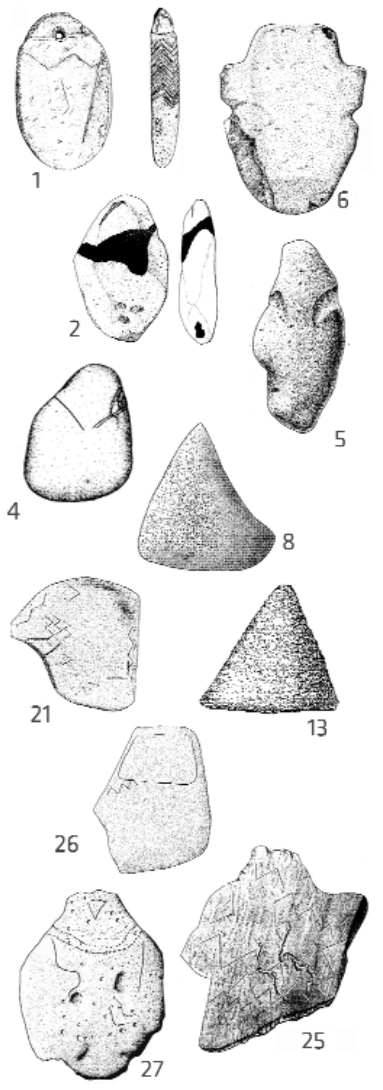

De sencillas formas geométricas a elementos más elaborados, las opciones son muchas.

En el área de acceso a los monumentos, las figuras antropomorfas realizadas sobre canto o sobre soportes pétreos de tamaño pequeño y mediano presiden rituales de comida y bebida, probablemente convocados por los herederos de los ancestros a los que representan. Estas piezas son susceptibles de una enorme movilidad, tanto por su tamaño como por la evidencia de que se encuentran en muchas ocasiones al aire libre absoluto. Pero cuando se documentan, ocupan posiciones normativas, lo que indica que alguien se responsabilizó del mantenimiento de este orden de modo constante, además de que debieron gozar de un notable respeto a lo largo del uso de estas áreas abiertas (BUENO RAMÍREZ et al., 2006; 2007a; 2007c).

Los datos de Los Millares (Santa Fe de Mondújar, Almería) son pioneros en ese aspecto: los betilos y diversas formas pétreas asociados a ellos se disponían a la entrada de algunos monumentos (ALMAGRO BASCH Y ARRIBAS PALAU, 1963). Otro caso de estudio conocido es el dolmen de Dombate (La Coruña), en cuyo espacio exterior se agregan piezas trabajadas muy explícitamente antropomorfas, y piezas poco trabajadas, que ocupan idéntica posición, reiterando significados parejos (BELLO DIEGUEZ, 1994). Estas agregaciones se documentan en otros megalitos del ámbito gallego (FÁBREGAS VALCARCE Y VILASECO, 2006: 29), pero nos interesa dejar constancia de que no se trata de una especialización noroccidental. Los depósitos interiores de Trincones I, en Alcántara (Cáceres) (BUENO RAMÍREZ et al., 2007c), o del Anta da Horta (Oliveira, 2006) confirman que fueron bastante más abundantes en toda la Península (BUENO RAMÍREZ et al., 2005b), y auguran expectativas futuras de gran interés en el momento que las áreas abiertas de los megalitos se excaven más ampliamente. En otros casos estos elementos se disponían incluso en áreas delimitadas, como ocurre en el dolmen de Lagunita I (Santiago de Alcántara, Cáceres). En su zócalo, se depositaron vasijas con comida y bebida, algunas placas decoradas, hachas pulimentadas y puntas de flecha. Un pequeño menhir o betilo se conservaba en uno de los accesos, y hemos de suponer que el otro ha desaparecido por los recientes trabajos de las máquinas de sembrar encinas.

Lo mismo podemos decir de las agregaciones de piezas antropomorfas muebles en el interior de los monumentos. Su disposición reitera pautas constantes a la entrada de las cámaras, y apunta al mismo orden y res- 
peto que preside las áreas abiertas. La relación que a veces presentan con estructuras en piedra o en madera, "altares", justifica complejas ritualidades tanto en el interior como el exterior de los megalitos.

\section{IMÁGENES ANTROPOMORFAS COMO IDENTIFICADORES VISIBLES}

Si los cantos y pequeñas figuras antropomorfas a las que arriba nos hemos referido son elementos perceptibles, en la medida en que son conocidos y respetados en el interior y zona exterior inmediata a los megalitos, los menhires y estelas de tamaños destacados constituyen la referencia más notable de los territorios megalíticos. Los primeros, al igual que algunos grabados poco visibles, proporcionan argumentos para analizar el territorio reconocido por sus autores (BUENO RAMÍREZ Y BALBÍN BEHRMANN, 2000a; 2000b; EDMONDS, 1999; SONNEFELD, 1972), mientras que los segundos son constatación de los territorios reivindicados, mediante el argumento de hacer visibles a los grupos que los erigieron.

También los menhires disponen de antecedentes en el mundo de los cazadores y recolectores, no sólo en las rocas de sugerentes formas a las que más arriba hemos hecho referencia, y a las que Calado (2004) conecta con la referencia visible de los hábitats de los primeros agricultores o en destacados elementos naturales (BRADLEY, 1997; BUENO RAMÍREZ et al., en prensa b). Hablamos de la presencia de viejos menhires de madera que tuvieron un papel en la identificación de las áreas habitaciones y funerarias de los mesolíticos europeos. La documentación de este tipo de hitos en contextos mesolíticos del norte de Europa (RUST, 1943) tiene datos muy contundentes en los menhires de la cabecera de las tumbas K y J de Höedic, en el VI milenio cal BC (CASSEN Y VAQUERO LASTRES, 2004).

En la Península lbérica, las fechas más antiguas se asocian a los menhires del suroeste, muchos de ellos imbricados en áreas de habitación con cerámicas impresas (CALADO, 1997, 2004; GOMES, 1994). Cronologías radiocarbónicas obtenidas de muestras procedentes de su fosa de cimentación (Oliveira, 1997), o por otras metodologías físico-químicas (GOMES, 1997a; CALADO et al., 2004) sitúan estos hitos en relación con la marcación de los lugares de hábitat de los primeros agricultores del oeste.

Recientemente hemos argumentado que la conexión menhires-hábitats es la misma que la de dólmenes-hábitats (BUENO RAMÍREZ et al., 2008), lo que adquiere mayores connotaciones al verificar que algunos megalitos se originan en la erección previa de menhires (GARCÍA SANJUÁN et al., 2006a; GAVILÁN CEBALLOS Y VERA RODRÍGUEZ, 2005). Por tanto sería la referencia a los ancestros el elemento agregador de unos y otros, lo que propone que los menhires constituirían una imagen evocadora de los mismos, sugiriendo un probable contenido funerario implícito, que se concreta en reiteradas asociaciones a necrópolis o a monumentos megalíticos (BUENO RAMÍREZ et al., 2004a).

Su visibilidad y protagonismo no acaban con la primera fase del megalitismo, como algunos autores sostienen (CALADO, 2004, 2006). Los datos de los que disponemos en el propio suroeste sustentan una cronología larga, la misma que podemos argumentar para el propio decurso del ritual megalítico (BARROSO BERMEJO et al., 2007; BUENO RAMÍREZ et al., 2004a; 2004c). Si los modelos de relación menhires, dólmenes, hábitats, utilizados para la Europa atlántica han demostrado su operatividad en la Península Ibérica (BUENO RAMíREZ et al., 2004a; CALADO, 1997), no deberíamos olvidar que la arqueología bretona, por destacar un caso de estudio clásico, ha demostrado sobradamente la continuación en la erección y uso de los menhires. Los cuatro grandes menhires de Château Bü se asocian a tumbas de la Edad del Bronce realizadas sobre el túmulo de este dolmen (BRIARD et al., 1995: 37).

\section{LAS IMÁGENES DEL MUNDO SUBTERRÁNEO}

Al interior de los megalitos, cada uno de sus soportes se concibe como un personaje (BUENO RAMÍREZ Y BALBÍN BEHRMANN, 1994; 1996b;
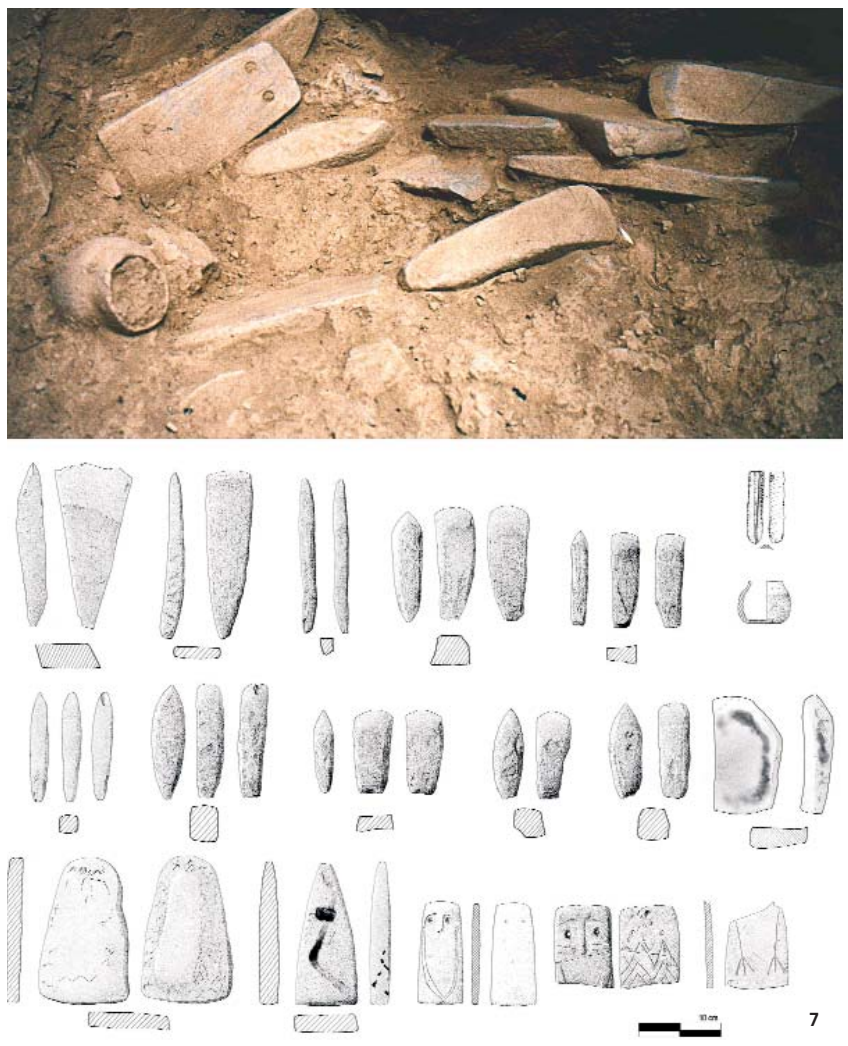


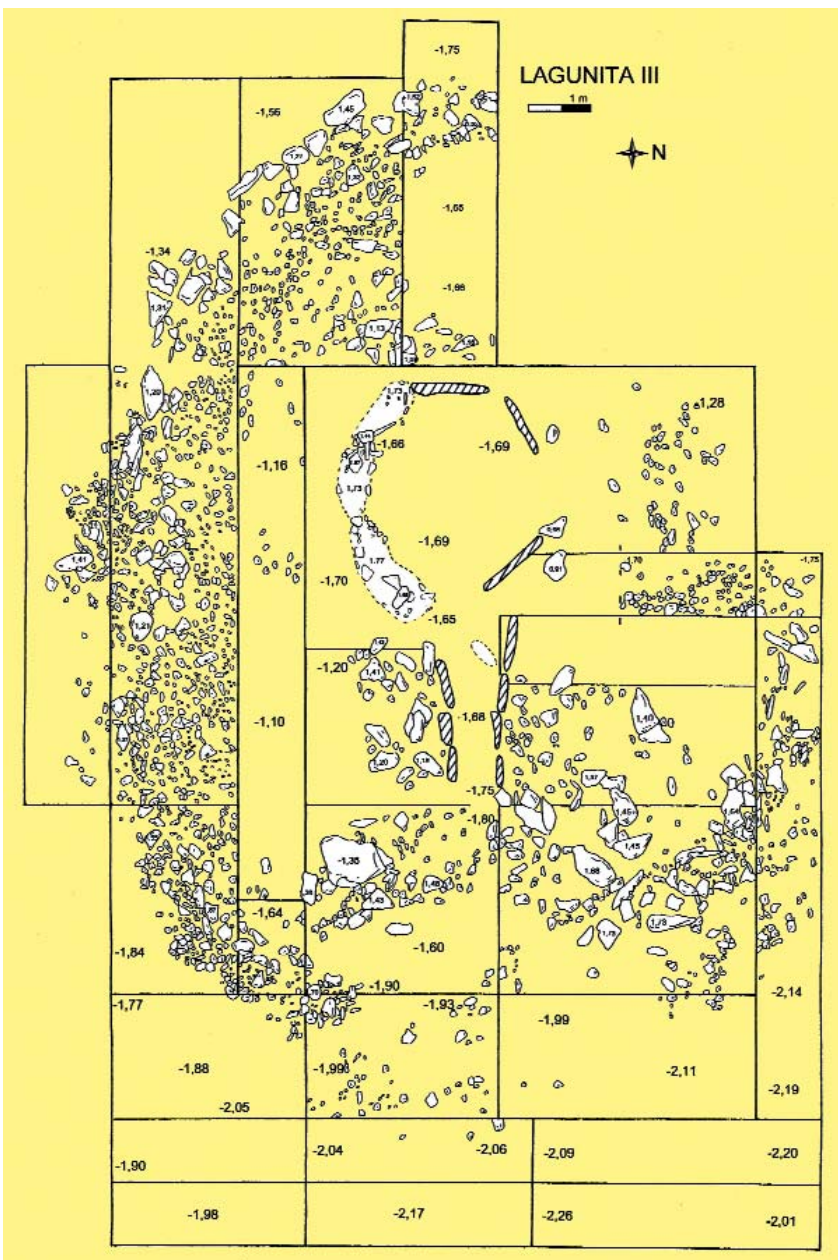

1997b: 1 13), confirmando la hipótesis de L'Helgouach (1996), tanto en el megalitismo bretón (CASSEN, 2007: 60), como en el megalitismo ibérico (BUENO RAMÍREZ et al., 2007a). La acumulación de estelas reutilizadas constata que sea cual fuere su posición inicial, al aire libre o en otro megalito más antiguo, su significado perduró, pues en su uso reciente también representan imágenes antropomorfas, insistiendo en el protagonismo de éstas en las mitografías megalíticas.

Hace algún tiempo que venimos señalando la intrínseca conexión entre ortostatos y estelas, recurriendo al análisis de las grafías de los monumentos decorados. La mayor parte de ellas son temáticas geométricas, que remiten a las documentadas en piezas muebles contemporáneas que, como las placas decoradas del suroeste, aparecen revestidas con mantos de motivos similares (BUENO RAMÍREZ, 1992). Sólo las piezas situadas en lugares destacados del frontal de la cámara, de la entrada a la misma, de la entrada al corredor o de los accesos abiertos ostentan algún
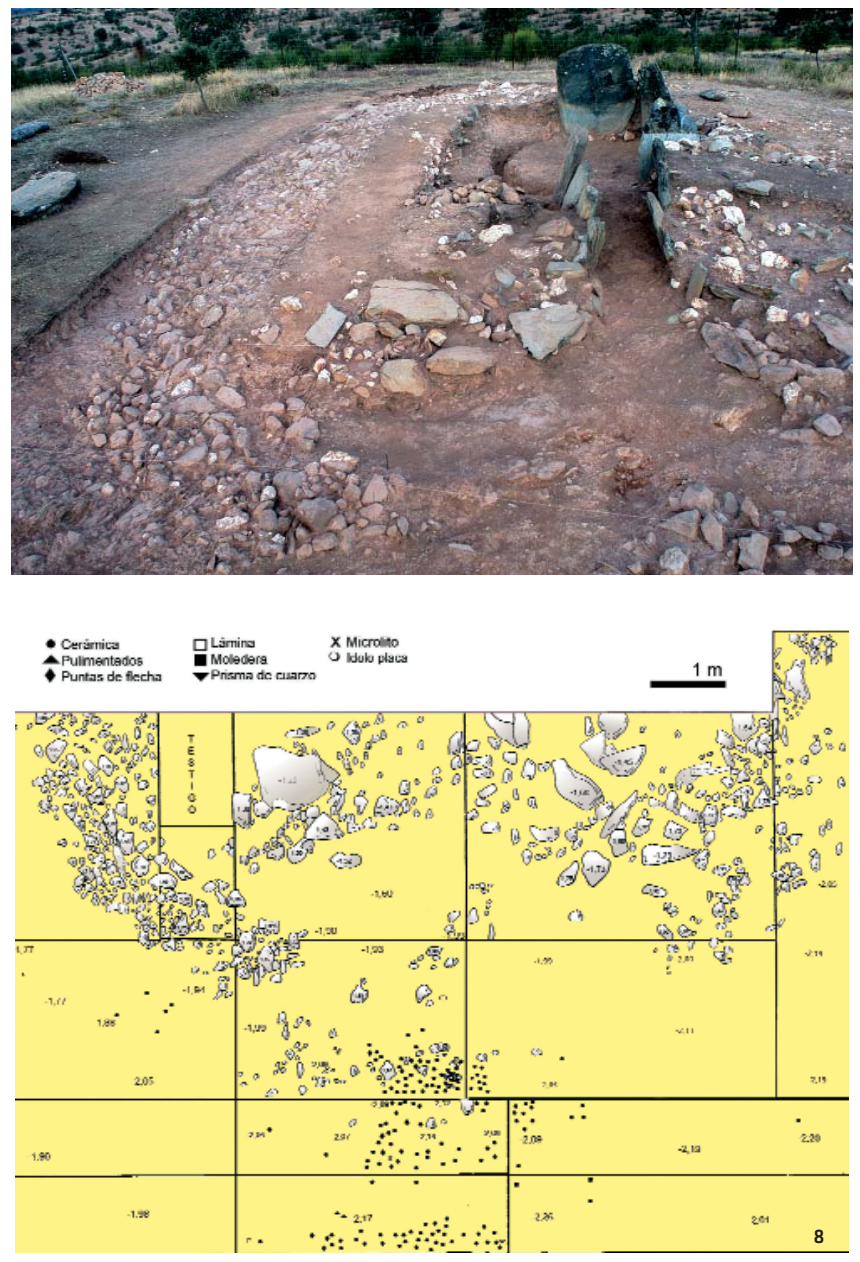

grado de individualización, que permite analizar escenas desarrolladas por personajes específicos. En general, tienden a sobrepasar las tipologías de los antropomorfos esquemáticos clásicos, presentando formas que se repiten en territorios concretos. Hemos propuesto valorarlos en el mismo sentido que Leroi-Gourhan (1971) interpretó algunos signos del arte de Paleolítico Superior europeo, como especializaciones identitarias (BUENO RAMÍREZ Y BALBÍN BEHRMANN, 1996b; 1997a; 2003; BUENO RAMÍREZ et al., 2007a).

La concentración de antropomorfos tipo "piel estirada" en las zonas frontales de las cámaras del noroeste, no tiene parangón en el sur, por el momento. Mientras que algunos personajes sedentes, como los detectados en Soto II (Trigueros, Huelva) (BALBín BEHRMANN Y BUENO RAMÍREZ, 1996), o en Alberite I (Villamartín, Cádiz) (BUENO RAMÍREZ Y BALBín BEHRMANN, 1996a; BUENO RAMÍREZ et al., 1999) tampoco poseen referencia, hasta ahora, en el norte. 
Este tipo de propuesta se verifica también en materiales muebles. Ya defendimos que las placas con decoración geométrica del suroeste mostraban diseños diferentes en relación con su ubicación geográfica, lo que interpretamos como la constatación de talleres con recorridos de intercambio (BUENO RAMÍREZ, 1992) y como evidencia identitaria. Definimos un patrón "clásico", el más extendido y común, tanto en piezas muebles como en soportes parietales (BUENO RAMÍREZ, 1990; 1995), o en ortostatos-estela (BUENO RAMÍREZ et al., 2005a), y formas más restringidas e individualizadas, que visualizan cierta territorialidad. De ser así, la presencia de placas como la de Mamaltar de Vale das Fachas (BUENO RAMÍREZ, 1992: fig. 27), al norte de Portugal, o las placas-estela tipo Peña Tú (BUENO RAMÍREZ et al., 2005a) estarían indicando interacciones evidentes entre los constructores de megalitos de una y otra zona (BUENO RAMÍREZ et al., en prensa c). Al igual que la presencia de figuras con ojos-soles muy destacados, tatuajes y formas tendentes al cilindro, en el oeste, valora interacciones con el sureste (HURTADO PÉREZ, 2007), que avalan otros productos culturales

La fijación de imágenes antropomorfas como referencias identitarias en el ritual megalítico aporta información para el análisis de las interacciones más frecuentes en el mundo peninsular. Y si las que acabamos de mencionar entre el norte y el suroeste, y entre éste y el sureste se vienen percibiendo en la Prehistoria Reciente ibérica a partir de otros parámetros materiales, la documentación de conexiones con el mundo atlántico, que argumentamos desde los años 80 a partir del registro gráfico (PIÑÓN VARELA Y BUENO RAMÍREZ, 1983; BUENO RAMÍREZ Y BALBÍN BEHRMANN, 1996a; BUENO RAMÍREZ et al., 1999; 2007a), posee rotundas confirmaciones en la procedencia de las piedras de color verde de megalitos franceses en yacimientos peninsulares (HERBAULT Y QUERRÉ, 2004).

\section{IMÁGENES DE PODER: DE HACHAS Y BÁCULOS A ESPADAS, PUÑALES Y ALABARDAS}

Tanto al interior de los megalitos, como en los menhires, los personajes individualizados se acompañan de algún objeto que de seguro los caracteriza para los "lectores" de estos monumentos. En su evolución temporal, menhires y estelas presentan una tendencia marcada desde los objetos realizados en piedra y madera (fundamentalmente hachas y báculos), cuya funcionalidad armamentística es cuando menos ambigua,

\begin{tabular}{|c|c|c|c|c|}
\hline Menhir & Contexto & Decoración & Fecha & Bibliografía \\
\hline Meada & Fosa de implantación & Grabado & Utc - 4452: $6022+40$ BP & Oliveira, 1997 \\
\hline Padrâo & Fuego con restos de moluscos & Grabado & $\begin{array}{l}\text { ICEN-645: } 5366 \mathrm{cal} \mathrm{A.C.} \\
\text { ICEN-873: } 5484 \mathrm{cal} \text { A.C. }\end{array}$ & Gomes, 1995 \\
\hline Quinta da Queimada & Materia prima del menhir & Grabado & $\begin{array}{l}\text { Shftd } 02013 \\
5925+/-175 \text { BT }\end{array}$ & Calado et al., 2004 \\
\hline
\end{tabular}

\begin{tabular}{|c|c|c|c|c|c|c|}
\hline Monumento & Arq & Tipo & Localización & Decoración & C14 & Bibliografía \\
\hline Abamia & & Estela & Ortostato cámara & G & & Jordá, 1977 \\
\hline Alberite I & G & Estela & Ortostato cámara & G & Beta-80602 5320+/-90 BP & Bueno et al., 1999 \\
\hline Alberite II & & Estela & & c & & Inédito \\
\hline Alcalar 4 & Th & Frag. Menhir & Ortostato corredor & c & & Veiga, 1889 \\
\hline Anta das Cabeças & CC & Menhires & Ortostato cámara & G & & Leisner, 1949 \\
\hline Azután & CC & Estela & Cámara & G & Ly-4578: 5750+/-130 BP UGRA-288: 5060+/-90 BP & Bueno et al., 2005 \\
\hline Baradal & ๔ᄃ & Estela & Ortostato corredor & $G / P$ & & Jordá, 1977 \\
\hline Casasde D. Pedro & $\mathrm{cc}$ & Menhires & Ortostato cámara & G & & Gavilán y Vera, 2005 \\
\hline Châ de Santinhos 1 & ๔C & Estela? & Túmulo & G & Gif-6784: $4990+/-50 \mathrm{BP}$ & Jorge, 1986 \\
\hline Chafé & C & Estela & Ortostato cámara & G & & Silva, 1994 \\
\hline Coitemil & Cs & Estela & Ortostato cámara & c & & Bradley, 2004 \\
\hline Huerta de las Monjas & CCL & Estela & Ortostato cámara & G & & Bueno, 1988 \\
\hline Llanos de la Belleza & CC & Menhires & Cámara y corredor & G & & García Sanjuán et al., 2006 \\
\hline Maimón 2 & CCL & Estela & Ortostato cámara & G & & Bueno et al., 1999 \\
\hline Menga & G & Estela & Cobertura cámara & c & & Inédito \\
\hline Morelles & CC & Estela & Cobertura cámara & G & & Tarros et al., 1982 \\
\hline Moreno 3 & c & Estela & Suelo cámara & G & & Ferrer, 1976 \\
\hline Orca do Tanque & $\mathrm{CCL}$ & Estela & Cobertura corredor & G & & Comes y Carvalho, 1995 \\
\hline Orca dos Padrôes & $\mathrm{CCL}$ & Estela & Cobertura cámara & G & Oxa-4484: 4960+/-65 BP & Gomes y Carvalho, 1995 \\
\hline Os Campiños 6 & cС & Estela & Ortostato cámara & c & & Fábregas y Vilaseco, 2006 \\
\hline Os Muiños & cС & Estela & Ortostatos cámaras & $\mathrm{P}$ & & Carrerra, 2007 \\
\hline Pedra Escorregadia & ๔С & Frag. Menhir & Ortostato cámara & G & ICEN-847 3370-2934 B.C & Gomes, 1993 \\
\hline Pendilhe & CCL & Estela & Cobertura cámara & G & & Leisner, 1998 \\
\hline Pozobal & C & Estela & Túmulo & c & & Serna, 1997 \\
\hline Romeral & Th & Frag. Menhir & Ortostato corredor & G & & Inédito \\
\hline Soto & G & Estela & Ortostato corredor & G & & Obermaier, 1924 \\
\hline Viera & CCL & Estela & Cobertura corredor & G & GrN-17628: 4650+/-250 BP & Inédito \\
\hline Zambujeiro & $\mathrm{CCL}$ & Estela & Ortostato cámara & G & & Bueno y Balbín, 1992 \\
\hline
\end{tabular}


11. Comparativa entre la decoración geométrica de algunas placas decoradas del suroeste de la Península lbérica y la del Dolmen de Santa Cruz (Asturias) / Fuente. Bueno Ramírez et al., $2005 a$

12. Personaje sedente grabado en el frontal del Dolmen de Soto II (Trigueros, Huelva) / FOTO: R, DE BALBÍN BEHRMANN

13. Placas-estela del norte de la Península lbérica / Fuente: Bueno RAmírez et al. 2006
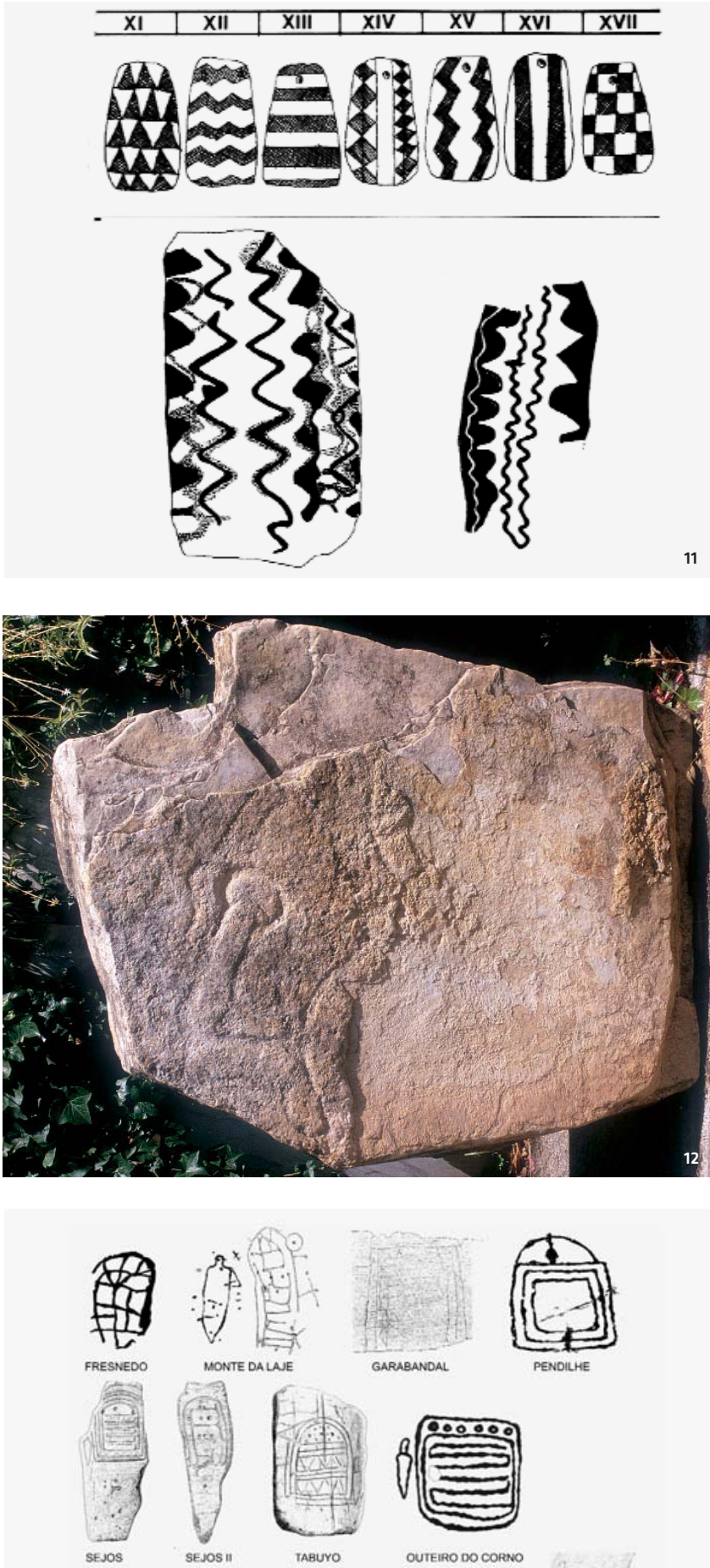

OUTERO DO CORNO
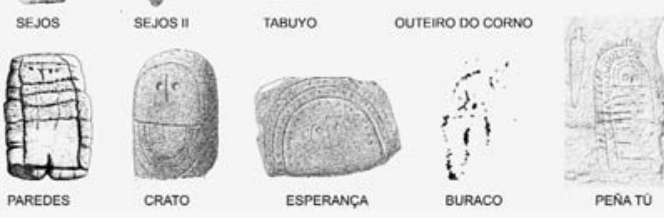

por objetos que sin duda son armas, esencialmente espadas o puñales y alabardas (BUENO RAMÍREZ et al., 2005a). Ciertamente que esta evolución puede resultar discutible, pues en ocasiones las diferencias de cronología son amplias. Pero lo es menos cuando se reiteran pautas gráficas, como las que venimos señalando entre las estelas centro-occidentales y las de la Edad del Bronce del suroeste (BUENO RAMÍREZ, 1990; 1995), o cuando piezas armadas se integran en paisajes funerarios plenamente megalíticos (BUENO RAMÍREZ et al., 2005c; en prensa c).

Como proponíamos en un trabajo reciente, los datos de ortostatos-estela asociados a hachas en el norte son relativamente abundantes, entendiendo que el objeto que E. Shee (1981) denominó "the thing" por no poder identificarlo de forma más concreta, haría alusión a este tipo de útil (BUENO RAMÍREZ Y BALBíN BEHRMANN, 1997a). El sur aporta en los últimos años buenos ejemplos. El más difundido es la estela-menhir (ortostato 21) reutilizada del Dolmen de Soto (Trigueros, Huelva), que en su posición actual presenta un antropomorfo esquemático con un hacha enmangada en la mano (BALBÍN BEHRMANN Y BUENO RAMÍREZ, 1996). Espectaculares hachas de fuerte aire atlántico, acompañadas de báculos con grafías similares a las detectadas en los grabados al aire libre del Tajo, son las que ocupan anverso y reverso de un soporte del dolmen de Alberite II, en Cádiz (BUENO RAMÍREZ et al., 2007a). En Alberite I, ya señalamos una forma de "the thing" en el ortostato 3 (BUENO RAMÍREZ et al., 1999). Éstas tienen en la estela-menhir 56 del crómlech de Almendres otro ejemplo (BUENO RAMÍREZ et al., 2005a: fig. 21). También hachas enmangadas, asociadas a báculos, aparecen en el ortostato que cierra el monumento de Vale de Rodrigo, en Évora (LARSSON, 2001).

Precisamente hachas y báculos definen las asociaciones presentes en los menhires del oeste. Estos objetos serían los característicos de las representaciones ancestrales. Su reiteración en los ortostatos-estela del Sur avala la identificación de parámetros gráficos que unen el pasado con el presente, en el marco de los primeros constructores de megalitos. Otro tipo de armas, aunque menos comunes, sí tienen papel en los megalitos. Las más Ilamativas serían las formas cortantes detectadas en Soto (BALBÍN BEHRMANN Y BUENO RAMÍREZ, 1996: fig. 8) o en Alberite I (BUENO RAMÍREZ et al., 1999).

La representatividad de puñales campaniformes en estelas del norte (BUENO RAMÍREZ Y FERNÁNDEZ MIRANDA, 1981; BUENO RAMÍREZ et al., 2005a; en prensa c), y del sur ${ }^{\top}$ de la Península Ibérica, coincide cronológicamente con el cambio entre hachas de piedra y puñales de cobre asociados en los ajuares funerarios del norte de Europa (SALANOVA, 2003). Las primeras en el ámbito de la simbología de los agricultores y los puñales como evidencia de la metalurgia relacionada con la extensión del campaniforme y de los ítems de prestigio que lo han hecho famoso como elemento de análisis de la desigualdad social. La aparición de armas 

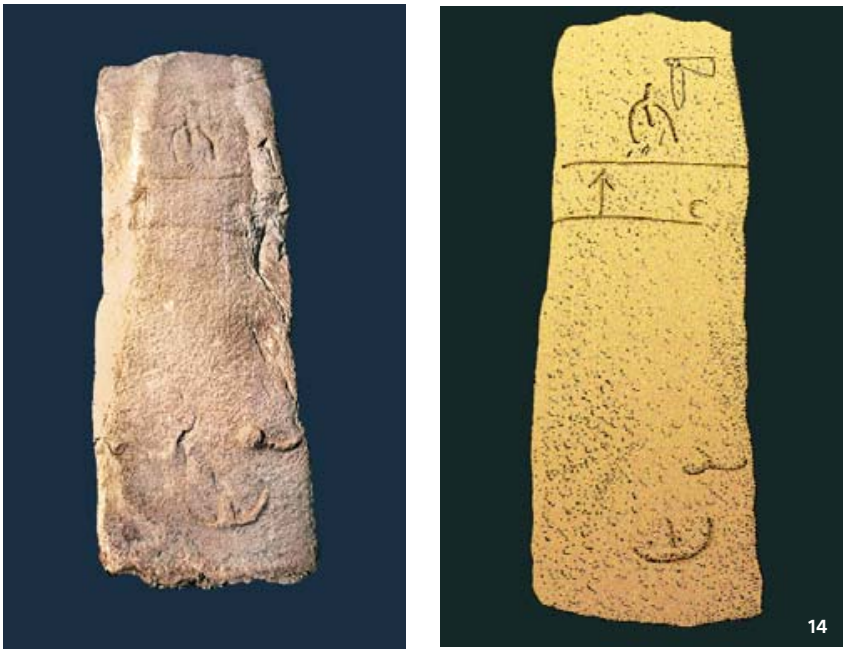

metálicas como objetos asociados a los ancestros, dibujados como guerreros masculinos (BRADLEY, 1998), manifiesta el tránsito entre lo colectivo, la imagen del ancestro o ancestros del grupo, a lo individual, el uso de los recursos de la tradición a favor de figuras de poder en el marco de individualidades o de caudillos tribales. El mantenimiento de las vestimentas talares con motivos geométricos que caracterizaban los más antiguos ortostatos-estela en las nuevas imágenes de poder se suma a los parámetros que reiteran el lazo con la tradición de los ancestros.

Las estelas del grupo centro-occidental son un significativo caso de estudio para la valoración de este proceso (BUENO RAMÍREZ, 1990; 1995; BUENO RAMÍREZ et al., 2005a). Quizás su grafía más identificadora es el tocado de la cabeza, que aparece en estelas con contexto megalítico y que continúa en el marco de las estelas del suroeste. Este grupo ha sido denominado por Celestino Pérez (2000) como "estelas diademadas", en la hipótesis de conectar estas figuras con personajes femeninos. Pero lo cierto es que cuando sus especificaciones son mayores, dibujan personajes guerreros, con cinturón, a veces con armas, caso de la alabarda de Hernán Pérez VI, las hojas de puñal de Agallas, de Serra Boulhosa (BUENO RAMÍREZ et al., 2005a: fig. 27 y 38) o el cuchillo de Alto da Escrita (VILAÇA et al., 2001)

También las escasas escenas megalíticas poseen referencias posteriores para insistir en ese recorrido que conecta la mitología de los primeros agricultores y la de los grupos metalúrgicos. Por un lado las que podríamos catalogar como de jerarquización, o como representaciones heráldicas (BUENO RAMÍREZ et al., 2000), en la que una figura de mayor tamaño está acompañada por otras más pequeñas y situadas en posiciones inferiores en el soporte. Por otro, las escenas de caza, en las que concurren figuras humanas, cánidos, cérvidos e imágenes solares, un compendio mitográfico que podemos seguir, sin dificultad, hasta prácticamente la Edad del Hierro (BUENO RAMÍREZ et al., 2005a).
Todo ello sin dejar de lado la documentación de paisajes funerarios de largo recorrido en los que destacadas representaciones humanas en piedra se constituyen en elemento agregador e identificador de la sucesión de ocupaciones funerarias y habitacionales. Peña Tú, Sejos o Soalar son significativos casos de estudio al norte (BUENO RAMÍREZ et al., en prensa c), que ahora se pueden contrastar con datos del sur de la Península (BUENO RAMÍREZ et al., 2004a).

Las necrópolis de monumentos de pequeño tamaño de Las Hurdes, en algunos de los cuales se ubican estelas calcolíticas con tocado diademado (BUENO RAMÍREZ, 1990; BUENO RAMÍREZ Y GONZÁLEZ CORDERO, 1995), tuvieron continuidad en los mismos territorios funerarios, que fueron señalizados con estelas del Bronce Final. Piezas reutilizadas como la estela de Sao Martinho (VILAÇA et al., 2004) corroboran la fuerte conexión entre las imágenes antropomorfas megalíticas y las del Bronce Final, además de apuntar a que estas secuencias de estelas en los territorios funerarios del suroeste no son únicas.

El proyecto de investigación realizado en Almadén de la Plata (Sevilla) por el equipo de García Sanjuán (2005) aporta otro caso a estas imágenes antropomorfas identificadoras de áreas funerarias. El sepulcro de Palacio III ostenta una estela indicadora en la parte superior del túmulo (Estela 1) del mismo tipo, materia prima y decoración que la que indicó la cámara más antigua (Estela 3), en la actualidad absorbida por la más reciente. La Estela 2, antes citada, se realizó en arenisca roja, como los soportes del dolmen albergado en el mismo túmulo. Esta espectacular agregación funeraria tenía en las presencias antropomorfas la representación más visible del lugar de enterramiento de los ancestros. La documentación de dos estelas del Bronce Final, en su entorno (GARCÍA SANJUÁN et al., 2006b) asociadas a una acumulación de guijarros de cuarzo blanco de posible carácter tumular, confirma una secuencia gráfica asentada en figuras humanas identificadoras de las áreas de enterramiento, por una parte. Por otra, deja constancia del valor de la tradición en ellas, pues la que alberga dos figuras tiene en la adornada por la diadema una asociación guerrero-figura ancestral. Aquélla que repite todos los parámetros gráficos de las estelas centro-occidentales, cuyos ejemplos se datan desde fines del IV al II milenio cal BC (BUENO RAMÍREZ et al., 2005 a).

La recurrencia observable entre los primeros megalitos y los menhires, la contrastada en la reutilización de estelas o menhires en arquitecturas del megalitismo avanzado (BUENO RAMÍREZ et al., 2007a), y la continuidad entre las estelas megalíticas y las del Bronce Final, conocidas como "de guerrero" o "tartésicas", avalan los argumentos que proponemos, como un elemento a considerar en la interpretación de los ejemplares del Bronce Final. Analizar éstos sin tener plena consciencia del recorrido cronológico previo al que nos estamos refiriendo supone deformar una realidad ideológica en la que pesan más las continuidades que las rupturas. 

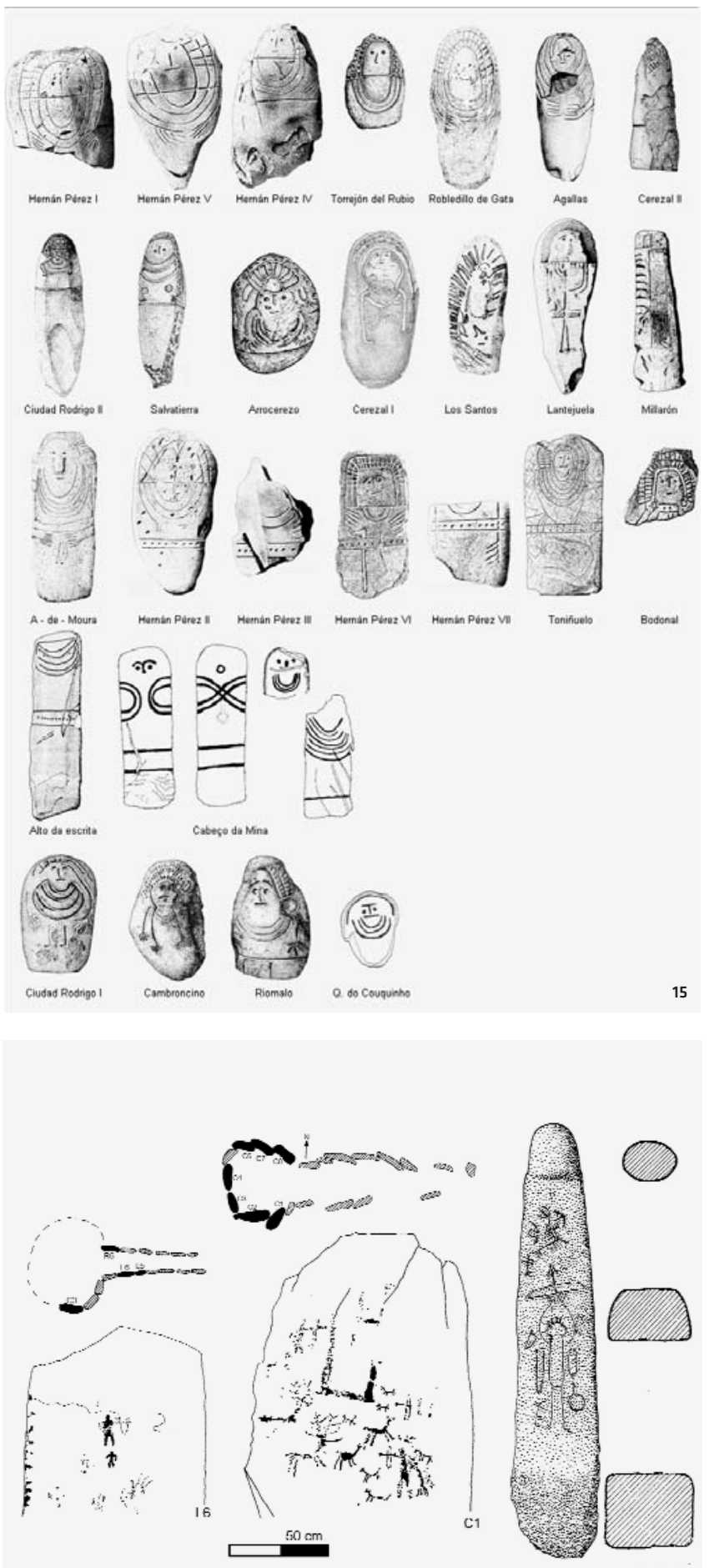

Incluso la misma evolución de los monumentos hacia la notable sencillez de espacios coincide con la de la erección de una sola pieza, la que en los viejos megalitos detentaba el papel más destacado en el frontal de la cámara, o la entrada de ésta, como caracterizadora de las sistemáticas identitarias o de otro carácter que se querían expresar, sin ser la menor, la alusión expresa a los ancestros como justificación de la posición en un determinado territorio. Curiosamente la misma acepción que parece asumible en el caso de la erección de los más antiguos menhires.

\section{PASADO, PRESENTE Y FUTURO ESCRITO EN LAS PIEDRAS}

Del protagonismo animal que pudo encerrar historias de trasfondo humano en el Paleolítico, al protagonismo sin disfraces de las figuras humanas a partir del Neolítico, el cambio más nítido es precisamente la base subsistencial. No hay argumento más claro para explicitar este aserto que las asociaciones de objetos que presiden la transformación de las primeras imágenes antropomorfas con visibilidad paisajística, los menhires, como protagonistas del papel de los ancestros en la justificación del asentamiento habitacional. Hachas y báculos, que poco después protagonizan las imágenes de poder en los dólmenes, el lugar más nítido de culto a los ancestros.

La fijación de estas formas en soportes perdurables es la que propone una historia escrita en las piedras desde, cuando menos, el Paleolítico Superior, confirmando que hubo un sistema ideográfico de expresar mitografías comúnmente reconocidas. Las expectativas de perdurabilidad de este mensaje son evidentes a partir de la búsqueda de materias primas de carácter pétreo, pues es de suponer que muchas se han perdido al haberse realizado en madera y, por qué no, fijado en tejidos que no han llegado hasta nosotros.

El cómputo de superficies decoradas a lo largo del Paleolítico Superior sugiere que el nivel de implementación simbólica fue muy alto en los lugares relacionados con el mundo cotidiano, las áreas de habitación y explotación económica, con las que podemos relacionar no sólo los yacimientos al aire libre del occidente peninsular, sino una parte importante de los contextos en cueva (BALBÍN BEHRMANN Y ALCOLEA GONZÁLEZ, 1999; BUENO RAMÍREZ Y BALBÍN BEHRMANN, 2001; BUENO RAMÍREZ et al., 2004a). Esa percepción de cantidad de escrituras en el paisaje se confirma a lo largo del Holoceno en la amplitud de soportes y de técnicas empleadas en marcar y definir un territorio ya reconocido con anterioridad, un territorio tradicional (BUENO RAMÍREZ, en prensa).

El papel que en los marcadores gráficos de la Prehistoria Reciente poseen las imágenes antropomorfas refleja una intensificación en el aspecto 


\section{Nota}

${ }^{1}$ Como la estela de Garrovillas, Cáceres, que en la actualidad estamos estudiando junto con el equipo de E. Cerrillo Cuenca 17a y b. Agregación de megalitos y áreas de habitación en torno a las estelas de Soalar (Navarra) y Sejos (Cantabria) / FUENTE: Bueno RAmíREZ et al., EN PRENSA c. simbólico dirigida muy específicamente a las figuras armadas, que se posicionan en lugares destacados del ámbito cotidiano y de los ámbitos funerarios. Su protagonismo camina hacia el sincretismo expresivo, acabando por hacerse el elemento imprescindible para aludir al poder simbólico de los ancestros en las estelas armadas de la Edad del Bronce.

Analizando las pautas de este proceso se constata la imbricación entre los recursos gráficos aplicados a las figuraciones de los ancestros y los que aparecen en situaciones más individualizadas, justificando la hipótesis de que son caudillos o jefes armados los que toman las imágenes de la tradición, como referente ideológico para representar y justificar su poder. Estas asociaciones entre mitos de origen/personajes emblemáticos/guerreros son muy semejantes a las que tenemos documentadas en tiempos históricos en las que los personajes más destacados del orden social, religioso o económico se esfuerzan por identificarse con los elementos de la tradición religiosa para revestir su poder de origen divino, transmutando el poder terrenal en poder sagrado y utilizando éste como un parámetro más para sustentar el orden social (BUENO RAMÍREZ y BALBÍN BEHRMANN, 2006b; BUENO RAMÍREZ et al., 2001).

La reiteración de pautas gráficas que hemos definido como la exhibición de la tradición y la continuidad de mitografías de largo recorrido cronológico no significan inmovilismo, sino apoyos ideológicos para una transformación social que favorece la posición privilegiada de unos pocos, asentada en la exhibición de su linaje y de su origen (BUENO RAMÍREZ y BALBÍN BEHRMANN, 2006a; 2006b).

Las representaciones antropomorfas expresan, como muchos otros de los factores que se valoran en los indicios de jerarquización, tipos de enterramiento, objetos exóticos, rituales alcohólicos, etc., la continuidad simbólica e ideológica entre los grupos productores y los grupos metalúrgicos del sur de Europa. Continuidad entendida como recurso ideológico, en la que las referencias antropomorfas que agregaron a los primeros agricultores se incluyen en la construcción de los depósitos de linajes concretos. Los símbolos que los identificaban, hachas y báculos, se exhiben al interior y al exterior de los sepulcros, asociándose a estos linajes. La transformación de las estelas tradicionales en guerreros armados, mediante la incorporación de puñales, espadas y alabardas, se asienta en la mitografía del pasado.

Más que profundos cambios, habríamos de pensar en adaptaciones paulatinas a un statu quo, en el que las tensiones por el control de los medios de producción se resuelven mediante una estrategia de apropiación simbólica de territorios, que primero fueron reivindicados por los grupos productores y que, progresivamente, acaban por constituir sistemas de identificación y, por qué no, de derechos de paso y de uso. Las imágenes armadas de los ancestros transmitirían la coerción ideológica del pasado
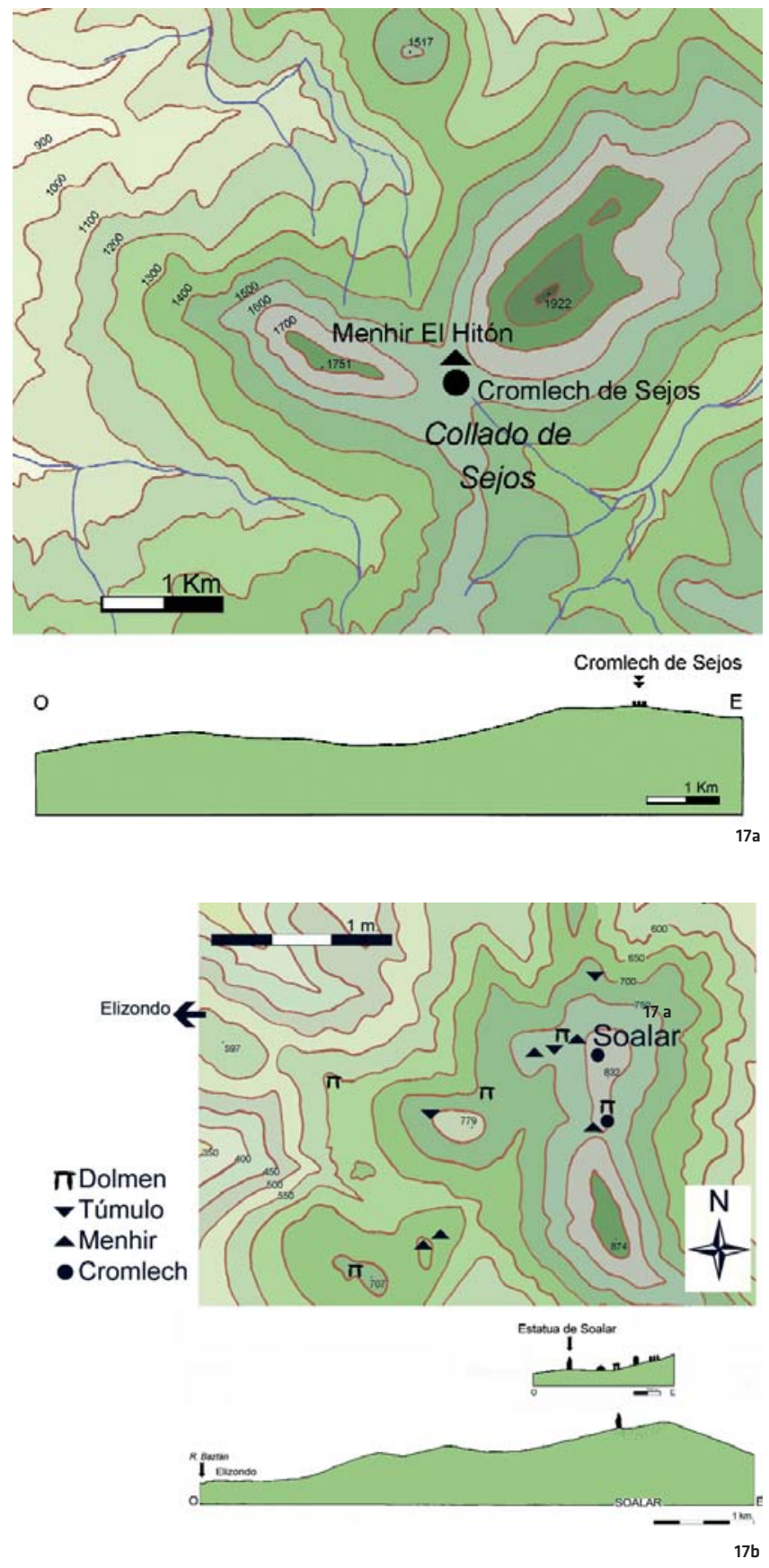

y su asociación con imágenes armadas la realidad de jefes con potencia real de agresión para quien traspasara los límites de esos derechos de uso y propiedad. Tradición y herencia sustentarían el papel de líderes emergentes, con connotaciones heroicas e identitarias, constituyendo la base de las creencias y mitos que presiden las organizaciones sociales de la Edad del Bronce en el sur de Europa. 


\section{Bibliografía}

ALMAGRO BASCH, M.; ARRIBAS PALAU, A. (1963) El Poblado y la Necrópolis Megalíticos de Los Millares (Santa Fe de Mondújar, Almería). Madrid: Biblioteca Praehistórica Hispana III, 1963

AUBRY, T. (2001) L'occupation de la basse vallée du Côa pendant le Paléolithique Supérieur. En Zilhao, l:; Aubry, T; Carvalho, A.F. (ed.) Les premiers hommes modernes de la péninsule lbérique. Actes du colloque de la commission VIII de I'UISPP. Lisboa: IPPAR, 2001, pp. 253-273

BALBÍN BEHRMANN, R.; BUENO RAMÍREZ, P. (1 996) Soto, un ejemplo de arte megalítico en el Suroeste de la Península. En Moure Romanillo, J. A. (coord.) El hombre fosil" 80 años después: volumen conmemorativo del 50 aniversario de la muerte de Hugo Obermaier. Santander: Universidad, 1996, pp. 467-505

BARROSO BERMEJO, R.; BUENO RAMÍREZ, P.; CAMINO MAYOR, J.; BALBÍN BEHRMANN, R. (2007) Fuentenegroso (Asturias), un enterramiento del Bronce Final - Hierro en el marco de las comunidades atlánticas peninsulares. Pyrenae, 38 (2)، 2007, pp. 7-32

BELLO DIÉGUEZ, J. M. (1994) Grabados, pinturas e ídolos en Dombate (Cabana,La Coruña) ¿Grupo de Viseu o grupo noroccidental? Aspectos taxonómicos y cronológicos. O Megalitismo no Centro de Portugal. Actas do Seminário. Viseu: Centro de Estudios Pré-históricos da Beira Alta, 1994, pp. 287-304

BRADLEY, R. (1997) Rock art and the Prehistory of Atlantic Europe. Londres: Routledge, 1997

BRADLEY, R. (1998) Invisible warriors. Galician weapon carvings in their Iberian context. En Fábregas Valcarce, R. (ed.) A Idade do Bronze en Galicia: Novas Perspectivas. Cadernos do Seminario de Sagadelos, 77, pp. 243-258

BREUIL, H. (1935) Les Peintures Rupestres Schémathiques de la Penínsule Ibérique. París: Lagny, 1935

BREUIL, H. (1974) 400 Siècles D'Art Pariétal. París: Reed, 1974

BRIARD, J.; GAUTIER, M.; LEROUX, G. (1995) Les mégalithes et les tumulus de Saint-/ust. Ille-et-Vilaine. Paris: Éditions du Comité des travaux historiques et scientifiques, 1995

BUENO RAMÍREZ, P. (1988) Los Dólmenes de Valencia de Alcántara. Excavaciones Arqueológicas en España 155. Madrid: Ministerio de Cultura, 1988

BUENO RAMÍREZ, P. (1990) Statues - menhirs et stèles anthropomorphes de la Péninsule Ibérique. L'Anthropologie, 94 (1), 1990, pp. $85-110$

BUENO RAMÍREZ, P. (1991) Megalitos en la Meseta Sur: los Dólmenes de Azután y La Estrella (Toledo), Excavaciones Arqueológicas en España 159. Madrid: Ministerio de Cultura, 1991

BUENO RAMÍREZ, P. (1992) Les plaques décorées alentejaines: approche de leur étude et analyse. L'Anthropologie, 96 (2-3), 1992 , pp. 499-572

BUENO RAMíREZ, P. (1995) Megalitismo, estatuas y estelas en España. Statue-stele e Massiincisi nell'Europa dell'etá del Rame. Notizie Archeologiche Bergomensi, 3, 1995, pp. 77-130

BUENO RAMÍREZ, P. (en prensa) Espacios decorados al aire libre del occidente peninsular. Territorios tradicionales de cazadores-re- colectores y de productores. En Balbín Behrmann, R. (ed.) Coloquio Internacional Arte Rupestre al aire libre. Salamanca (en prensa)

BUENO RAMÍREZ, P.; BALBÍN BEHRMANN, R. (1992) L'Art mégalithique dans la Péninsule Ibérique. Une vue d'ensemble. L'Anthropologie, 96, 1992, pp. 499-572

BUENO RAMÍREZ, P.; BALBÍN BEHRMANN, R. (1994) Estatuas-menhir y estelas antropomorfas en megalitos ibéricos. Una hipótesis de interpretación del espacio funerario. Homenaje al prof. Echegaray. Santander: Museo y Centro de Altamira, 1994, pp. 337 347 (Monografías 17)

BUENO RAMÍREZ, P.; BALBÍN BEHRMANN, R. (1996) La decoración del dolmen de Alberite. En Ramos Fernández, l.; Giles Pacheco, F. (ed.) El Dolmen de Alberite (Villamartín). Aportaciones a las Formas Económicas y Sociales de las Comunidades Neolíticas del Noroeste de Cádiz. Villamartín, Cádiz: Ayuntamiento de Villamartín, 1996, pp. 285-313

BUENO RAMÍREZ, P.; BALBÍN BEHRMANN, R. (1996) El papel del antropomorfo en el arte megalítico ibérico. Révue Archéologique del'Ouest, 8, 1996, pp. 97-102

BUENO RAMÍREZ, P.; BALBÍN BEHRMANN, R. (1997) Ambiente funerario en la sociedad megalítico ibérica: arte megalítico peninsular. En Rodríguez Casal, A. (ed.) O Neolítico Atlántico e As Orixes do Megalitismo. Santiago de Compostela: Universidad, 1997. pp. 693-718

BUENO RAMÍREZ, P.; BALBÍN BEHRMANN, R. (1997) Arte megalítico en sepulcros de falsa cúpula. A propósito del monumento de Granja de Toniñuelo (Badajoz). Brigantium, 10, 1997, pp. 91 -121

BUENO RAMÍREZ, P.; BALBíN, BEHRMANN, R. (2000) La grafía megalítica como factor para la definición del territorio. Arte Prehistórica. Metodología y Contextos. ARKEOS, 10, 2000, pp. 129-178

BUENO RAMÍREZ, P.; BALBíN BEHRMANN, R. (2000) Art mégalithique et art en plein air. Approche de la définition du térritoire pour les groupes producteurs de la Péninsule Ibérique. L'Anthropologie, 103 (3), 2000, pp. 427-458

BUENO RAMÍREZ, P.; BALBÍN BEHRMANN, R. (2001) Le sacré et le profane: notes pour l'interprétation des graphies préhistoriques péninsulaires. Révue Archéologique de l'Ouest, supplé, 9, 2001, pp. 141-148

BUENO RAMIREZ, P.; BALBÍN BEHRMANN, R. (2002) L'art mégalithique péninsulaire et l'art mégalithique de la façade atlantique. Un modèle de capillarité appliqué à l'art postpaléolithique ibérique. L'Anthropologie, 106, 2002, pp. 603-646

BUENO RAMÍREZ, P.; BALBíN BEHRMANN, R. (2006a) Arte megalítico en la Península Ibérica: contextos materiales y simbólicos para el arte esquemático. En Martínez García, l: Hernández Pérez, M. (ed.) Arte rupestre Esquemático en la Península Ibérica. Comarca de Los Vélez, pp. 57-84

BUENO RAMÍREZ, P.; BALBín BEHRMANN, R. (2006b) Between power and mythology: evidence of social inequality and hierchachisation in Iberian megalithic art. En Díaz-Del-Río, P.; García Sanjuán, L. (ed.) Social Inequality in Iberian Late Prehistory. Oxford: BAR International Series, 1525, 2006, pp. 37-52

BUENO RAMÍREZ, P.; BALBíN BEHRMANN, R.; ALCOLEA GONZÁLEZ, J. J. (2003) Prehistoria del lenguaje en las sociedades cazadoras y productoras del sur de Europa. En R. de Balbín Behrmann;
P. Bueno Ramírez (ed.) El arte prehistórico desde los inicios del siglo XXI: Primer Symposium Internacional de Arte Prehistórico de Ribadesella. Ribadesella: Asociación Cultural Amigos de Ribadesella 2003, pp. 13-22

BUENO RAMÍREZ, P.; BALBÍN BEHRMANN, R.; ALCOLEA GONZÁLEZ, J. J. (2007) Style V dans le bassin du Douro. Tradition et changement dans les graphies des chasseurs du Paléolithique Supérieur européen. L'Anthropologie, 111, 2007, pp. 549-589

BUENO RAMÍREZ, P.; BALBín BEHRMANN, R.; BARROSO BERMEJO, R. (2004a) Application d'une méthode d'analyse du territoire à partir de la situation des marqueurs graphiques à l'intérieur de la Péninsule Ibérique: le Tage International. L'Anthropologie, 108, 2004, pp. 653-710

BUENO RAMÍREZ, P.; BALBíN BEHRMANN, R.; BARROSO BERMEjO, R. (2004b) Arte megalítico en Andalućáa: una propuesta para su valoración global en el ámbito de las grafías de los pueblos productores del Sur de Europa. Mainake, XXVI, 2004, pp. 29-62

BUENO RAMÍREZ, P.; BALBÍN BEHRMANN, R.; BARROSO BERMEJO, R. (2005a) Hierarchisation et métallurgie: statues armés dans la Péninsule Ibérique. L'Anthropologie, 109, 2005, pp. 577-640

BUeNO RAMÍREZ, P.; BALBín BeHRMANN, R.; BARROSO BERMEJO, R. (2005c) La estela armada de Soalar Valle del Baztán (Navarra). Trabajos de Arqueología Navarra, 18, 2005, pp. 5-40

BUENO RAMÍREZ, P.; BALBÍN BEHRMANN, R.; BARROSO BERMEJO, R. (2007a) Chronologie de l'art mégalithique ibérique: C14 et contextes archéologiques. L'Anthropologie, 11 1, 2007, pp. 590-654

BUENO RAMÍREZ, P.; BALBÍN BEHRMANN, R.; BARROSO BERMEJO, R. (2008) Ideología de los primeros agricultores en el Sur de Europa: las más antiguas cronologías del Arte Megalítico ibérico. Cuadernos de Arte Rupestre

BUENO RAMÍREZ, P.; BALBíN BEHRMANN, R.; BARROSO BERMEJO, R. (en prensa a): Pintura megalítica en Andalucía. Homenaje a la Profesora Pilar Acosta. Spal, 16

BUENO RAMÍREZ, P.; BALBíN BEHRMANN, R.; BARROSO BERMEJO, R.; ALDECOA QUINTANA, A.; CASADO MATEO, A.; GILES PACHECO, F.; GUTIÉRREZ GONZÁLEZ, J. M.; CARRERA RAMÍREZ, F. (1999) Estudios de arte megalítico en la necrópolis de Alberite. Papeles de Historia, 4, 1999, pp. 35-60

BUENO RAMÍREZ, P.; BALBÍN BEHRMANN, R.; BARROSO BERMEJO, R.; ALDECOA QUINTANA, A.; CASADO MATEO, A. (2000) Dólmenes en Alcántara (Cáceres). Un proyecto de consolidación e información arqueológica en las comarcas extremeñas del Tajo. Balance de las campañas de 1997 y 1998. Extremadura Arqueológica, VIII, 2000, pp. 129-168

BUENO RAMÍREZ, P.; BALBÍN BEHRMANN, R.; DÍAZ-ANDREU, M.; ALDECOA QUINTANA, A. (1998) Espacio habitacional/espacio gráfico: grabados en el término de la Hinojosa (Cuenca). Trabajos de Prehistoria, 55, 1998, pp. 101-120

BUENO RAMíREZ, P.; BALBÍN BEHRMANN, R.; GONZÁLEZ CORDERO, A. (2001) El arte megalítico como evidencia del culto a los antepasados. A propósito del dolmen de la Coraja. Quaderns de Prehistoria y Arqueología, 22, 2001, pp. 47-72

BUENO RAMÍREZ, P.; BARROSO BERMEJO, R.; BALBÍN BEHRMANN R. (2004) Construcciones megalíticas avanzadas de la cuenca interior del Tajo. El núcleo cacereño Spal 13,2004 PD. 83-112 
BUENO RAMÍREZ, P.; BARROSO BERMEJO, R.; BALBÍN BEHRMANN R. (2007c) El dolmen de Lagunita III: rituales y símbolos de la tradición en el megalitismo del Tajo Internacional. En Cerrillo Cuenca, E:; Valadés, J. (coord.) Los Primeros Campesinos de La Raya. Aportaciones Recientes al Conocimiento del Neolítico y Calcolítico en Extremadura y Alentejo. Cáceres: Consejería de Cultura y Turismo, Museo de Cáceres, 2007, pp. 65-93

BUENO RAMÍREZ, P.; BARROSO BERMEJO, R.; BALBÍN BEHRMANN R. (en prensac) El metal y los símbolos de los ancestros en el Norte de la Península Ibérica. XV UISSPP Congress, Lisboa, 2006

BUENO RAMÍREZ, P.; BARROSO BERMEJO, R.; BALBÍN BEHR MANN R.; CARRERA RAMÍREZ, F. (2006) Megalitos y Marcadores Gráficos en el Tajo Internacional: Santiago de Alcántara (Cáceres). Santiago de Alcántara: Ayuntamiento, 2006

BUENO RAMÍREZ, P.; FERNÁNDEZ-MIRANDA, M. (1981) EI Pe ñatú de Vidiago (Llanes, Asturias). Altamira Symposium. Madrid: Ministerio de Cultura, 1981, pp. 441-458

BUENO RAMÍREZ, P.; GONZÁLEZ CORDERO, A. (1995) Nuevos datos para la contextualización arqueológica de estatuas-menhir y estelas antropomorfas en Extremadura. Trabalhos de Antropologia e Etnología, 35 (I), 1995, pp. 95-106

CALADO, M. (1997) Cromlechs alemtejanos e a arte megalítica. Brigantium, 10, 1997, pp. 287-297

CALADO, M. (2004) Entre o céu e a terra. Menires e arte rupestre no Alentejo Central. En Calado, M. (2004) Sinais de Pedra. I Colóquio Internacional sobre Megalitismo e Arte Rupestre (Évora, 2003). Évora: Fundação Eugénio de Almeida, 2004 (CD ROM)

CALADO, M. (2006) Les menhirs de la Péninsule Ibérique. En Joussaume, R.; Laporte, L.; Scarre, C. (ed.) Origin and Development of the Megalithic Phenomenon of Western Europe. Proceedings of the International Symposium (Bougon, France, October 26th30th 2002). Niort: Conseil Général de Deux Sèvres, 2006, pp. 613-636

CALADO, D.; NIETO, J. M.; NOCETE CALVO, F. (2004) Menires, símbolos e organizaçâo social. $\mathrm{O}$ extremos SW peninsular. En Calado, M. (2004) Sinais de Pedra. I Colóquio Internacional sobre Megalitismo e Arte Rupestre (Évora, 2003). Évora: Fundação Eugénio de Almeida, 2004 (CD ROM)

CASSEN, S. (2007) Un pour tous, tous contre un... Symboles, mythes et histoire d'après une stèle morbihannaise du Ve millénaire. En Baray, L.; Brun, P. ; Testart, A. (ed.) Pratiques Funéraires et Societés. Nouvelles Approches en Archéologie et en Anthropologie Sociale. Dijon: Editions de l'Université de Dijon, 2007, pp. 37-68

CASSEN, S.; VAQUERO LASTRES, J. (2004) El deseo pasmado. En Calado, M. (2004) Sinais de Pedra. I Colóquio Internacional sobre Megalitismo e Arte Rupestre (Évora, 2003). Évora: Fundação Eugénio de Almeida, 2004 (CD ROM)

CELESTINO PÉREZ, S. (2000) Estelas de Guerrero y Estelas Diademadas. La Precolonización y Formación del Mundo Tartésico. Barcelona: Bellaterra, 2000

COUREAUD, C. (1985) L'Art Azilien. Origine et Survivance. XX Supplé. Gallia Préhistoire. Paris: CNRS, 1985

DELPORTE, H. (1979) L'Image de la Femme dans l'Art Préhistorique. Paris: Picard, 1979
(1994) L'Art Gravé Azilien. De la Technique à la Signification. Paris: CNRS, 1994

D'ERRICO, F.; POSSENTI, L. (1998) L'art mobilier épipaléolithique de la Méditerranée occidentale: comparaisons thématiques et technologiques. En Sacchi, d. (ed.) XXIV Congrès Préhistorique de France. Les Facies leptolithiques du Nord- Ouest Méditerranéen milieux naturels et culturels. Paris, 1998, pp. 93-1 16

EDMONDS, M. (1999) Ancestral Geographies of the Neolithic Lanscape, Monuments and Memory. Londres: Routledge, 1999

FÁBREGAS VALCARCE, R.; VILASECO VÁZQUEZ, X.I. (2006) En torno al megalitismo gallego. En Carrera Ramírez, Fi, Fábregas Valcarce, R. (ed.) Arte Parietal Megalítico en el Noroeste Peninsular. Santiago de Compostela: Tórculo Edicións, 2006, pp. 11-36

GARCÍA SANJUÁN, L. (2005) Grandes piedras viejas, memoria y pasado. Reutilizaciones del Dolmen de Palacio III (Almadén de la Plata Sevilla) durante la Edad del Hierro. En Celestino Pérez, S; jiménez Ávila. J. (ed.) El Periodo Orientalizante. Actas del III Simposio Internocional de Arqueología de Mérida. Protohistoria del Mediterráneo Occidental (Mérida, 5-8 de Mayo de 2003). Anejos de Archivo Español de Arqueología 35. Mérida: CSIC, 2005, pp. 595-604

GARCÍA SANJUÁN, L.; WHEATLEY, D. (2006) Recent investigations of the megalithic landscapes of Sevilla province, Andalusia Dolmen de Palacio III. En Joussaume, R.; Laporte, L.; Scarre, C. (ed.) Origin and Development of the Megalithic Phenomenon of Wester Europe. Proceedings of the International Symposium (Bougon France, October 26th-30th 2002). Niort: Conseil Général de Deux Sèvres, 2006, pp. 473-484

GARCíA SANJUÁN, L.; RIVERA JIMÉNEZ, T; WHEATLEY, D. W. (2006) Prospección de superficie y documentación gráfica en el Dolmen del Llano de la Belleza (Aroche, Huelva). Anuario Arqueológico de Andalucía/2003. Tomo III. Actividades Puntuales y Sistemáticas. Sevilla: Consejería de Cultura de la Junta de Andalucía 2006, pp. 181-192

GARCÍA SANJUÁN, L.; WHEATLEY, D. W.; FÁBREGA ÁLVAREZ, P.: HERNÁNDEZ ARNEDO, M. I.: POLVORINOS DEL RÍO, A. (2006) Las estelas de guerrero de Almadén de la Plata (Sevilla). Morfología, tecnología y contexto. Trabajos de Prehistoria, 63 (2). 2006, pp. 135-152

GAVILÁN CEBALLOS, B.; VERA RODRÍGUEZ, J. C. (2005) Neolítico y megalitismo prefunerario en Andalucía. En Arias Cabal, P. Ontañón Garć́a, R.; García-Morcó, C. (ed.) III Congreso del Neolítico en la Península Ibérica. Cantabria: Universidad, 2005. pp. 535-54

GOMES, M. V. (1 994) Menires e cromeleques no complexo cultural megalítico Portugués. Trabalhos recentes e estado da questâo. 0 Megalitismo no Centro de Portugal. Estudos Pré-históricos, 2, 1994, pp. 317-342

GOMES, M. V. (1997) Megalitismo do Barlovento algarvio. Nova síntese. Setúbal Arqueológica, 1 1-12, 1997, pp. 147-190

GOMES, M. V. (1997) Estatuas-menhires antropomórficas do Alto Alentejo. Descobertas recentes e problemática. Brigantium, 10, 1997, pp. 255-279

GONÇALVES, V.; BALBÍN BEHRMANN, R.; BUENO RAMÍREZ, P. (1997) A estela-menir do Monte da Ribeira (Reguengos de Monsaraz, Alentejo, Portugal). Brigantium, 10, 1997, pp. 235-254
HERBAULT, F: QUERRE, G. (2004) La parure néolithique en variscite dans le sud de l'Armorique. Bulletin de la Societé Préhistorique Française, t.101, 3, 2004, pp. 497-520

HURTADO PÉREZ, V. (2008) Ídolos, estilos y territorios de los primeros campesinos en el sur peninsular. En Cacho, C:; Maicas, R:; Martínez, M...; Martos, J.A. (coord.) Acercándonos al Pasado. Prehistoria en 4 Actos. Madrid: Ministerio de Cultural (CD ROM)

LARSSON, L. (2001) Decorated façade?. A stone with carvings from the megalithic tomb Vale Rodrigo, monument 2, Alentejo, southern Portugal. Journal of Iberian Archaeology, 3, 2001, pp. 35-46

LEROI-GOURHAN, A. (1971) Préhistoire de l'Art Occidental. Paris: Mazenod, 1971 ( 2 a edición aumentada)

LE ROUX, CH.T. (1985) New excavations at Gavrinis. Antiquity, 59, 1985, pp. 183-187

L'HELGOUACH, J. (1983) Les idols qu'on abat (ou les vissicitudes des grandes stèles de Locmariaquer). Bulletin de la Societé Polymathique de Morbihan, t. 1 10, 1983, pp. 57-68

L'HELGOUACH, J. (1996) De la lumière aux ténèbres. Révue Archéologique de l'Ouest, suppl 8, 1996, pp. 107-123

OLIVEIRA, J. (1997) Datas absolutas de monumentos megalíticos da Bacia hidrográfica do río Sever. En Balbín Behrmann, R.; Bueno Ramírez, P. (ed.) II Congreso de Arqueología Peninsular, Tomo I. Zamora: Fundación Rei Afonso Henriques, 1997, pp. 229-239

OLIVEIRA, J. (2006) Patrimonio Arqueológico da Coudelaria do Alter e As Primeiras Comunidades Agropastoris. Évora: Universidade de Evora/Colibrí, 2006

O'SULLIVAN, M. (1997) On the meaning of megalithic art. Brigantium, 10, 1997, pp. 23-35

PIÑón VARELA, F.; BUENO RAMíREZ, P. (1983) Los grabados del núcleo dolménico de Los Gabrieles (Valverde del Camino, Huelva). Homenaje al Profesor Martín Almagro Basch. Madrid: Ministerio de Cultura, 1983, pp. 445-455

RUST, A. (1943) Die alt und mittelsteinzeitlichen Funde von Stellmoor. Neumünster: Karl Wachlholtz, 1943

SALANOVA, L. (2003) Heads North: analysis of bell beaker graves in Western Europe. Journal of Iberian Archaeology, 5, 2003, pp. 163-169

SONNENFELD, J. (1972) Geography perception and the behavorial environment. En English, P.W.; Mayfield, R.C. (ed.). Man, Space and Environment. Oxford: Oxford University Press, 1972, pp. 244252

VILACA, R.; CRUZ, D.; TOMAS, A.; NUNO, J. (2001) A estatuamenir de Ataúdes (Figueira de Castelo Rodrigo, Guarda) no seu contexto regional. Estudos Pré-históricos, IX, 2001, pp. 69-82

VILAÇA, R.; SANTOS, A. T.; MARQUÉS, J. N. (2004) Catálogo: 76, 77 y 78. Arqueología: coleccçôes de Francisco Tavares proença junior. Castelo Branco, 2004, pp. 159-166 